\author{
Journal of Analytic Divinity \\ International Refereed Journal \\ E-ISSN: 2602-3792 \\ Aralık/December, 2020/4 (2): ss-pp 99-126
}

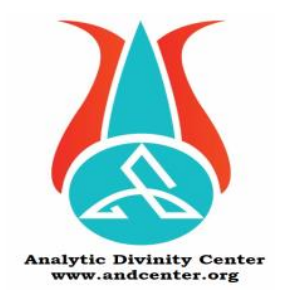

\title{
Etik Yönetim Penceresinden Kutadgu Bilig Değerlendirmesi
}

An Evaluation On The Kutadgu Bilig From Ethics Management Perspective

\author{
Yaşar Uzun \\ Sayıştay Uzman Denetçisi, Sayıştay Başkanlığı \\ Principal Auditor, Turkish Court of Accounts \\ Ankara, Turkey, yasaruzun@sayistay.gov.tr \\ https://orcid.org/0000-0003-3803-0611
}

\section{Makale Bilgisi | Article Information}

Makale Türü / Article Type: Araştırma Makalesi / Research Article

Geliş Tarihi / Date Received: 9 A ğustos/Agust 2020

Kabul Tarihi / Date Accepted: 1 Aralık/December 2020

Yayın Tarihi / Date Published: 15 Aralık/December 2020

Yayın Sezonu / Pub Date Season: Kış-Aralık/ Winter-December

DOI: http://doi.org/10.46595/jad.778396

Cite as / Atıf: Uzun, Yaşar. "Etik Yönetim Penceresinden Kutadgu Bilig Değerlendirmesi", Journal of Analytic Divinity 4/2 (December 2020), 99-126

İntihal: Bu makale, iThenticate yazılımınca taranmıştır. İntihal tespit edilmemiştir. Plagiarism: This article has been scanned by iThenticate. No plagiarism detected. Web: http://dergipark.gov.tr/jad | e-mail to: editorjand@gmail.com

Copyright $($ Published by Özcan Güngör, Ankara Yıldırım Beyazıt Üniversitesi, İslami İlimler Fakültesi / Ankara Yıldırım Beyazıt University, Faculty of Islamic Studies, Ankara-Turkey. Bütün hakları saklıdır. / All right reserved. 
Öz

Kamu yönetimlerinin halkın refah ve mutluluğunu sağlayacak şekilde geliştirilmesi, etik değer ve ilkeler temelinde şekillenecek yönetim anlayışlarının uygulamaya konulmasını zorunlu kılmaktadır. "Kamu yönetiminin temellerini oluşturacak, toplumca üzerinde mutabık kalınması gereken değer ve ilkeler nelerdir?", "Devlet-toplum ilişkilerinin ölçüleri nasıl olmalıdır?" gibi sorular etiğin felsefi boyuttan somut yaşam alanına taşınarak yaşanan ve yaşatılan bir kavram olmasının önünü açacaktır. XI. yüzyılda Balasagunlu Yusuf tarafından kaleme alınan Kutadgu Bilig, günümüz kamu yönetiminde etik değer ve ilkelere dayalı bir anlayışın gözetilmesi için asırlar öncesinden bizlere öneriler sunan Türk İslam geleneğinin bir şaheseridir. Eserin kamu yönetimi anlayışına, insanın dünya ve ahiret yaşam dengesine, yöneten ve yönetilen ilişkilerine sunduğu bakış açıları müellifinin tabiriyle "her iki dünya mutluluğunu sağlamaya" yöneliktir. Bu çalışmanın amacı; günümüz kamu yaşamında etik yönetim gereklilikleri hakkında bilgiler vererek, Kutadgu Bilig'in söz konusu gerekliliklere ilişkin bizlere söyledikleri hakkında farkındalık geliştirmektir. Bu bağlamda çalışmada Kutadgu Bilig'le ilgili genel bilgilendirmeler yapılarak, etik yönetim gereklilikleri üzerine eserin bizlere önerdiği hususlara yer verilecektir. Böyle bir çalışmanın günümüz kamu yönetimlerinde karşılaşılabilen etik kaynaklı sorunları aşabilmek üzere etik yönetim gerekliliklerinin daha iyi anlaşılabilmesi açısından bir düşünce ufku kazandıracağı ümit edilmektedir.

Anahtar Kelimeler: Siyâsetnâme, Kutadgu Bilig, Yûsuf Has Hâcib, Etik, Denetim

\begin{abstract}
Building and development of public management in a way that it enables welfare and happiness of public requires practicing of management understanding depending on ethical values and principles. Questions such as what should be the values and principles constituting essentials of public management and agreed by society as a whole and to what degree the relationship between the state and society should be maintained and kept, will lead the concept of ethics to be an experienced and living concept by carrying it from a philosophical dimension to the real life situations. Kutadgu Bilig, written by Yusuf of Balasagun, in the Xl th century, is a masterpiece of Turkish-Islamic tradition providing us advices ages ago in order to maintain an understanding depending on ethical values and principles in today's public management. The perspective of the Kutadgu Bilig regarding to public management understanding, the life balance between worldly life and afterlife, the relationship between managers and public officials etc. aims at happiness in this world and afterlife. Therefore, the purpose of this paper is to raise awareness regarding to what Kutadgu Bilig tells us in terms of ethical requirements of public management by giving information regarding today's ethical requirements. Thus, the paper will elaborate the ethical management advices of Kutadgu Bilig by giving general information about his work. It is expected that this paper provides a vision to the readers in terms of providing an understanding about the ethical management requirements to solve ethics related problems of today's public managements.
\end{abstract}

Keywords: Siyāset-nāme, Ḳutadgu Bilig, Yusuf Has Hacib, Ethics, Audit 


\section{Giriş}

Kamuyu yönetmek bir yönetim felsefesi gerektirmektedir. Söz konusu yönetim felsefesinin kilit taşlarını ise "değerler" oluşturmaktadır. Çelikkaya'ya göre değerler; "bir toplum, bir inanç, bir ideoloji içinde veya insanlar arasında kabul edilmiş, benimsenmiş ve yaşatılmakta olan toplumsal, insani, ideolojik veya ilahi kaynaklı her türlü duyuş, düşünüş, davranış, kural ya da kıymetlerdir" ${ }^{1}$ Söz konusu kamu yönetimi olduğunda, toplumun kamu yönetiminden beklentilerine göre benimsediği bir değerler setinden bahsetmek mümkündür. Bu değerler setine bakıldığında, "tarafsızlık", "dürüstlük", "liyakat", "nesnellik", "saydamlık", "hesap verebilirlik", "adalet", "eşitlik", "kamu yararın gözetme", "profesyonellik", "tutumluluk ve etkinlik", "hediye ve rüşvet almama" gibi değer ve ilkeler bütününün kamu görevlilerinin karar alırken ve hizmetleri yürütürken uymaları gereken temel esaslar olduğu anlaşılmaktadır. Eryılmaz'a göre "bu ilke ve değerleri benimseyen, karar ve işlemlerinde bunları uygulayan yönetime, "etik yönetim" denilmektedir. ${ }^{2}$

Etik yönetim gerekliliklerinin her zaman olduğu gibi bugün de önemli olduğu ve kamu yönetiminin paydaşları ve hatta uluslararası organizasyonlar (OECD, BM vb.) tarafından üzerinde düşünüldüğü, konuşulduğu, yazıldığı aşikârdır. OECD’nin yakın zamanda geliştirdiği "kamu dürüstlüğü gereklilikleri", kamu yönetimi açısından söz konusu etik yönetim gerekliliklerini birtakım ilkeler çerçevesinde tarif etmektedir. Söz konusu ilkeler uyarınca; kamu yönetiminin aktörleri arasında yer alan yöneticiler kamu dürüstlüğünü geliştirmede adanmışlık ve liderlik sergilemelidirler. Dürüstlüğe dayalı bir kamunun inşası için kamu yönetiminde kimin nelerden sorumlu olduğunu ortaya koyacak şekilde görev ve sorumluluklar tanımlanmalı, kamu görevlilerinden beklenen davranış standartları tarif edilmelidir. Tarif edilen davranış standartlarının uygulanması noktasında kamu görevlilerine gerekli eğitim ve rehberlik desteği sağlamak üzere gerekli tedbirler alınmalı ve dürüstlükle ilgili akıllara takılan hususları açıça görüşmeye dayalı bir anlayış geliştirilmelidir. Kamu dürüstlüğünün ayrılmaz bir vasfı olarak liyakate dayalı bir kamu yönetimi anlayışı güçlendirilmelidir. Kamu dürüstlüğünün güçlendirilmesi için toplumun her kesiminin desteği sağlanmalıdır. Dürüstlügüun kamu yönetiminde güçlendirilebilmesi açısından "iç kontrol ve risk yönetimi yaklaşımı" esaslı bir çerçeve uygulanarak, dürüstlük risklerini azaltmaya odaklı bir yaklaşım takip edilmelidir. Kamu dürüstlüğü açısından dürüstlük standartlarının ihlal edildiğine dair durumların yönetilmesine ve gerekli karşılıklarının verilebilmesine ilişkin mekanizmaların varlığı ve uygulanması önem taşımaktadır. Güçlü bir dürüstlük sistemi inşası için kamu yönetiminde dış denetim ve

\footnotetext{
${ }^{1}$ Hasan Çelikkaya, Fonksiyonel Ĕ̆itim Sosyolojisi (İstanbul: Alfa Yayınları, 1996), 168.

2 Bilal Eryılmaz, “Etik Kültürü Geliştirmek”, Türk İdare Dergisi 459 (Haziran 2008), 7.
} 
kontrol mekanizmaları oluşturulmalı, ayrıca kamu yönetiminde şeffaflık ve katılımcılık desteklenmelidir. ${ }^{3}$

Bu çalışmada, kültürel coğrafyamızın bizlere kazandırdığı bir siyasetname örneği olarak Yusuf Has Hacib'in "Kutadgu Bilig" adlı eseri ele alınacak, eserde bir çerçeve dahilinde etik yönetim gerekliliklerinin izlerinin bulunmasına çalışılacaktır.

$\mathrm{Bu}$ nedenle çalışmada temel amaç, yukarıda tarif edilen günümüz etik yönetim gerekliliklerine ilişkin olarak Kutadgu Bilig adlı eserde söz konusu gerekliliklerin nasıl ele alındığı hakkında bir bakış açısı kazandırmaktır. Bu nedenle çalışmada öncelikle Kutadgu Bilig'e dair genel bir bilgilendirme yapılacak, ardından etik yönetim fonksiyonlarına dayalı bir analize yer verilerek Kutadgu Bilig'de ortaya konan etik yönetim yaklaşımına dair tespitlere değinilecektir. Yapılan bu çalışmada, Ayşegül Çakan tarafından çevirisi yapılan “Yusuf Has Hacib-Kutadgu Bilig" adlı Türkiye İş Bankası yayını eserin okuma metni olarak esas alındığını hatırlatmakta yarar vardır. Söz konusu çeviri eser, "Kutadgu Bilig'in Fergana nüshasının tıpkıbasımındaki özgün metin esas alınarak günümüz diline manzum şekilde çevrilmiştir". ${ }^{4}$

\section{Kutadgu Bilig'e Dair}

\subsection{Siyasetname Örneği Olarak Kutadgu Bilig}

"Siyaset-nâme", "padişahlara ve büyük devlet adamlarına devlet işlerinde ve halka adaletli davranmaları yönünde ögüut veren, mensur ve manzum didaktik eserlere verilen addır". ${ }^{5}$ Siyasetnameler, "içeriğinde siyasi düşünce ve uygulamalarla ilgili tavsiyelerin yer aldığ1 özel bir edebi eser türüdür. Hükümdarlara "iyi hükümet etme (iyi idare etme)", "gücünü ve iktidarını koruma" yollarını gösteren rehber metinlerdir. Siyasetnameler doğrudan hükümdara ve diğer yöneticilere yönelik yazılan, ağırlıklı olarak siyasi nitelikte tavsiyeleri içeren bir nasihatname türüdür. Yöneticilerin sahip olması gereken hem beşeri hem ahlaki özellikleri ve yönetimi sırasında takip edeceği ilke politikaları içeren metinlerdir. Siyasetnameler "hem iyi insan hem de iyi yönetici olma bilgisi" öğretir. Siyasetnamelerin içeriği, yazılış amaçlarına göre farklılık gösterse de hepsi için ilk amacın “iyi yönetici olma” bilgisini öğretmek olduğu ifade edilmelidir. Hepsi iyi insan ve hükümdar olma, iktidarın devamını sağlama ve halkı refah ve mutlu etme amacına

\footnotetext{
${ }^{3}$ Organisation for Economic Co-operation and Development (OECD), Recommendation Of The Council On Public Integrity, (Paris: OECD Publishing, 2017), 13.

${ }^{4}$ Ayşegül Çakan, “Sunuş".Kutadgu Bilig. mlf.Yusuf Has Hacib,( İstanbul: Türkiye İş Bankası Kültürü Yayınlar1, 2017), Xİ.

${ }^{5}$ Ferit Devellioğlu, Osmanlıca-Tü̈kçe Ansiklopedik Lûgat (Ankara: Aydın Kitabevi, 2006), 959.
} 
yöneliktir". ${ }^{6}$ Bu yönüyle siyasetnameler, kamu yönetimi disiplininin gelişimine kaynaklık teşkil edebilecek temel yönetim esaslarını gerek döneminin, gerekse bugünün ve geleceğin insanına sunan referans eserlerdir. Bu eserler Türk İslam yönetim geleneğine dair kadim bilginin şekillenmesinde ve korunarak günümüze aktarılmasında temel yapı taşı işlevi görmektedirler.

"Kutadgu Bilig", Karahanlı bilgin ve devlet adamı Yusuf Has Hacib tarafindan 106970 yılında kaleme alınmış hikaye anlatımlı bir siyasetnamedir. Günümüze ulaşan ilk manzum siyasetname olması ve Fars geleneğinden ziyade Türk devlet ve yönetim geleneğini yansıtması, esere siyasetnameler arasında özgün bir mevki kazandırmaktadır". ${ }^{7}$ Kutadgu Bilig "kutlu kılan bilgi" anlamına gelmektedir8 ve "edebiyatın gücünden faydalanarak fert-devlet ilişkilerine dair çok önemli bilgiler sunan bir siyaset bilimi kitabıdır". 9 "Türk uluslarının ortak serveti olan XI yüzyıl yadigârı "Kutadgu Bilig", halkın sürekli peşinde olduğu özgürlük, bağımsızlık ve milli devlet gibi kutsal ülkülerini ifade eden bir tarihi kaynaktır. Kutadgu Bilig kendi döneminin tarihini, ahlaki görüşlerini, edebiyatını, dilini, felsefi bakış açısını yansıtan bir eser olmakla, dönemin devlet yönetim mekanizmasının öğrenilmesi açısından da eşsiz sanat eseridir". ${ }^{10}$ Kutadgu Bilig; devlet yönetiminin esasları, devlet yöneticilerinin görev ve sorumlulukları, sahip olmaları gereken vasıfları, devlet-toplum ilişkileri, dünya-ahiret dengesinin gözetilme gerekliliği gibi hususları ele alan, yöneticilere bu konuda rehberlik eden, izlenecek siyaseti (politikaları) belirleyen bir eserdir. Yönetime değer odaklı bakışın sağlandığı bu eserde, yönetici-yönetilen ilişkilerinin dayanması gereken düşünce zemini şiirsel bir dille ifade edilmiş, yönetimde karşılaşılan sorunları aşmak üzere müellif tarafından öngörülen siyaset felsefesi edebi bir üslupla okuyucusuna sunulmuştur.

Kutadgu Bilig' e "amaç" yönüyle bakıldığında, müellifin bu eseri kaleme almasındaki amacın düzenin bozulması üzerine hem devlet yöneticilerine ve hem de kendisinden sonra geleceklere söz söyleyerek dünya ve ahiret hayatında mutlu olmak için izlenmesi gereken yol hakkında bilgi vermek olduğu anlaşılmaktadır. ${ }^{11}$ Kutadgu Bilig, devletin adalet temelinde kalıcı olabilmesi için uyulması gereken esaslar hakkında insanların bilinçlenmesini amaçlamıştır. Bu nedenle devlet, yönetim, yönetici, başta adalet olmak

\footnotetext{
6 Ömer Dinçer, Siyasetnameleri Yeniden Okumak- Bir Yönetim Bilimci Gözüyle Geleneksel Siyasi Düşünce (İstanbul: Klasik Yayınları, 2018), 29-33.

7 Hasan Hüseyin Adalıŏlu, “Bir Siyasetname Olarak Kutadgu Bilig”, Doğumunun 990. Yılında Yusuf Has Hacib ve Eseri Kutadgu Bilig Sempozyumu Bildirileri, ed. Musa Duman. (Ankara: TDK Yayınlar1, 2011), 42-43.

8 Emir Çelik, Dünyayı Değiştiren Müslüman ve Türk Bilim Adamları (Ankara: Tutku Yayınevi, 2017), 160.

${ }^{9}$ Nazım H. Polat, "Edebî Değerler Açısından Kutadgu Bilig", Yazılışının 950. Yılı Anısına Uluslararası Kutadgu Bilig ve Türk Dünyası Sempozyumu Bildiriler Kitabı, ed. M. Fatih Kirişçioğlu, vd. (Ankara: Ankara Hacı Bayram Veli Üniversitesi Yayını, 2019), 103.

${ }^{10}$ Galibe Hacıyeva - Elbrus Veliyev, "Kutadgu Bilig" de Devlet İdareciliği Stratejisi”, Yazılışının 950. Yılı Anısına Uluslararası Kutadgu Bilig ve Türk Dünyası Sempozyumu Bildiriler Kitabı, ed. M. Fatih Kirişçioğlu vd, (Ankara: Ankara Hacı Bayram Veli Üniversitesi Yayını, 2019), 948.

11 Yusuf Has Hacib, Kutadgu Bilig, çev. Ayşegül Çakan, (İstanbul: Türkiye İş Bankası Kültür Yayınları, 2017), b. 192.
}

Journal of Analytic Divinity, https://dergipark.org.tr/tr/pub/jad Volume 4/2 
üzere kamu yönetiminde egemen olması gereken değerler gibi kavramlar üzerinde durmakta, yönetim işlerinde akıl ve bilgiye dayanarak hareket edilmesi, inanılan değerlerin toplum içerisinde yaşanarak hayata geçirilmesi gerektiğini vurgulamaktadır.

\subsection{Kutadgu Bilig'in Müellifi Hakkında}

Yusuf Has Hacib, 1019 yılı civarında Balasagun'da doğmuştur. Kutadgu Bilig'in sonradan eklenen mukaddimesinde yer aldığına göre, asil bir aileye mensup olan Yusuf Has Hacib, iyi bir tahsil görmüş, Arapça ve Farsçayı iyi bir düzeyde öğrenmiştir. Kutadgu Bilig' de yer alan bilgilere baktı̆̆ımızda, Yusuf Has Hacib' in hem söz konusu dilleri iyi bir düzeyde bildiğini, hem de dinî ve dünyevî ilimlere vakıf olduğunu söyleyebiliriz "Türbesi Kaşgar şehrinde bulunmaktadır". ${ }^{12}$ Yusuf Has Hacib, "aruz ölçüsüyle yazdığı eserini 1070 yılında Karahanlı hükümdarı Ulu Buğra Han'a sunmuş ve "Has Haciblik" unvanıla ödüllendirilmiştir. Yusuf Has Hacib, eserini doğduğu Balasagun'da (Kırgızistan) yazmaya başlamış, Kaşgar' da (Doğu Türkistan) tamamlamıştır". ${ }^{13}$

İlim ve erdem sahibi Yusuf Has Hacib, eserini her ne kadar on sekiz ay gibi bir zamanda yazarsa da, böyle bir eseri yazmak için bir hayli hazırlıklı olmak lazım geldiğini bilmek gerekir. Bu itibarla Yusuf, aldığı tahsilin yanında, toplumu gözlemleyen, devrinde olup bitenleri hakkıyla anlayıp çare bulmaya çalışan bir kimse olarak karşımıza çıkmaktadır. "Eserinden öğrendiğimiz kadarıyla her türlü bilgiyi edinmek, okumak, yazmak, güzel yazı, sanat, belagat ve bütün diller ile alfabeleri bilmek, şiir yazmak, çeşitli ilimlerle uğraşmak, insan topluluklarının hayatlarını gözden geçirmek, mesleklerle ilgili durumlar ve bunların özellikleri, tıpla ilgili bilgiler yanında hesap ve hendese öğrenmek, astronomi ilmine vakıf olmak, hatta rüya tabirinden tutun da şairlerin toplumdaki durumuna kadar hemen her konuya eserinde yer vermesi Yusuf'un bilgisinin ve görüş açısının genişliğini ortaya koymaktadır". ${ }^{14}$ "Kendi döneminin ünlü bilim adamı olan Yusuf Has Hacib, bilgin filozof, araştırmacı, psikolog, şair, ülke yönetim düzenini anlayabilen toplum uzmanı, Arap ve Fars edebiyatını çok iyi kavrayabilen edebiyatçı ve bütün Türk folklorunu ezbere bilen değerli şahsiyetlerden birisidir". ${ }^{15}$

\footnotetext{
12 Umut Kaya, “Kutadgu Bilig ve Yusuf Has Hacib'in Eğitimle İlgili Görüşleri”, Düzce Üniversitesi İlahiyat Fakültesi Dergisi I/I (2017), 3.

13 Çakan, "Sunuş", Xİ.

14 Kemal Yavuz, "Yusuf Has Hacib ve Kutadgu Bilig", İstanbul Üniversitesi Edebiyat Fakültesi Türk Dili ve Edebiyatı Dergisi 37/37 (2007), 144.

${ }_{15}$ Nurjan Narınbayeva Osmonova,"Kutadgu Bilig'deki Astrolojik ve Totemik Unsurlar", Yusuf Has Hacib'in Doğumunun 1000. Yılında Kutadgu Bilig Türk Dünya Görüşünün Şâheseri Uluslararası Sempozyumu Bildiriler Kitabı, ed. Ahmet Kavas vd. (İstanbul: İstanbul Medeniyet Üniversitesi Yayını, 2016), 580.
} 
Yusuf Has Hacib, yukarıda zikredilen pek çok alanda sahip olduğu bilgi ve meziyetleriyle, "yönetim işinin" kitabını yazarak siyaset felsefesinin temel tartışma konularından olan "adalet", "devlet", "bilgi", "iyi", "iyilik" gibi temel kavramların kültürel coğrafyamıza uygun tanımlarını yapmıştır. Eseriyle yönetim anlayışının soyuttan somuta taşınmasında önemli katkılar sunan Yusuf Has Hacib, kendisinden sonra gelecek yöneticilere "yönetim işinin nasıl yapılması gerektiği" noktasında önemli bir kılavuzluk hizmeti sunmaktadır. Eserinde yöneten yönetilen ilişkilerine yaptı̆̆1 tasnifler doğrultusunda detaylıca yer veren Yusuf Has Hacib, düşüncenin dışa vurumu olan davranışların değer odaklı sergilenmesi gerekliliğine de dikkati çekerek günümüz yönetim ve davranış bilimlerine önemli katkılarda bulunmuştur.

\subsection{Kutadgu Bilig'de Temel Karakterler}

Kutadgu Bilig'de dört karakter seçilmiş ve bu karakterler üzerinden devrin değerler sistemi, yöneten ve yönetilen ilişkileri tartışılmıştır. Bu şahıslardan Kün-Toğdı (İlig hükümdar), üslup, adalet, doğru yol ve kanunu; Ay-Toldı (Vezir), kut, saadet, devlet ve ikbali; Ögdülmiş (Vezirin oğlu), akıl, mantık ve feraseti; Odgurmış (Vezirin kardeşi) ise kanaat ve akıbeti temsil etmektedir". ${ }^{\prime 6}$

Eserin devlet yönetimine ışık tutan beyitleri göz önüne alındığında söz konusu karakterlerin vasıfları ile ilgili yapılan tespitlerden bazılarını şu şekilde ifade edebiliriz:

Kün-Toğdı Hakan; dürüst yaratılışlı, ılımlı tavırlı, doğru sözlü, bilgili ve akıllı bir şahsiyettir. $\mathrm{O}$, cesur yürekli, kötülüklere ve kötüye karşı durabilen, insanlığa ve halkına yardım için yapılacak iyilikleri bir siyaset yolu çerçevesinde yerine getiren bir kişiliğe sahiptir. ${ }^{17}$ Hakan, aynı zamanda doğru yasa yapmaya ve onu doğru şekilde uygulamaya önem vermektedir. ${ }^{18}$. Adaletli biri olan Hakan, "hizmetli ve halkın haklarının" neler olduğunun bilincindedir. ${ }^{19}$

Ay-Told1 (vezir); zeki, yiğit, akıllı ve bilgili bir şahsiyettir. $O$, güzel görünümlü, doğru dilli ve yumuşak sözlü birisidir. Her türlü erdeme vâkıftır ve bunlara uygun davranır. ${ }^{20}$ Güzel sözlü,21 mütevazı ve doğruluk üzere hareket eden Ay-Toldı, hizmet odaklı çalışmaktadır. ${ }^{22}$ İyi bir dinleyici olan Ay-Toldı, düzgün tavırlı, kendine karşı koyanı üzen,

\footnotetext{
16 Janagül Sametova, "Kutadgu Bilig'deki Alegorik İsimlerin Özellikleri ve Birbirleriyle İlişkileri”, Uluslararası Kutadgu Bilig Kurultayı Bildiri Özetleri, ed. Feyzi Ersoy- İrem Işıl Altun (Ankara: TDK Yayınları, 2019), 18.

17 Hacib, Kutadgu Bilig, b. 407-411.

18 Hacib, Kutadgu Bilig, b. 454.

${ }^{19}$ Hacib, Kutadgu Bilig, b. (2958, 2974, 5575.

${ }^{20}$ Hacib, Kutadgu Bilig, b. 463-465.

${ }^{21}$ Hacib, Kutadgu Bilig, b. 542.

22 Hacib, Kutadgu Bilig, b. 590.
}

Journal of Analytic Divinity, https://dergipark.org.tr/tr/pub/jad Volume 4/2 
boyun eğeni ise arzusuna kavuşturan, ${ }^{23}$ davranışları değişken olabilen, ${ }^{24}$ Hakan'a tam bağll1ıkla çalışan ${ }^{25}$ bir şahsiyete sahiptir. ${ }^{26}$

Vezirin oğlu Ögdülmiş; canını Hakan için feda etmeye hazır (1555), baba öğüdünü tutan, doğrudan ayrılmayan, ${ }^{27}$ gece gündüz çalışan, 28 bütün töreyi bilen, yasayı, iç ve dış işlerini düzenleyen bir kişiliktir. ${ }^{29}$ Alçak gönüllülükle davranan, herkesle iyi geçinen, tatlı dilli ve çokça dost edinen ${ }^{30}$ Ögdülmiş, aynı zamanda kendisine değer verildiğinde bunu suistimal etmeyen, değer verilmediğinde hizmetini kesmeyen bir şahsiyettir. $\mathrm{O}$, hazineyi ve malı iyi yönetmekte, işlerini doğrulukla yapmaktadır. İşlerinde şeffaflığı önemseyen Ögdülmiş, yazılı ve kayıtlı şekilde çalışan, Hakan'ın malını öz malı gibi gözeten, hizmette eğrilik göstermeyen ${ }^{31}$ bir kişilik sergilemektedir.

Ögdülmiş'in yakını olan Odgurmış ise, çok bilgili, bütün erdemlere sahip, zeki ve günahtan sakınan, hangi işe girse üstesinden gelebilen, doğru davranışlı, ama bu dünyadan yüz çeviren, insanlardan, şehir ve köylerden uzaklaşıp dağa çıkarak kendini ibadete veren, halkın ileri geleni, seçkin, bilgisiyle yol gösteren bir kişiliktir. ${ }^{32} \mathrm{O}$, bilgili, akıllı, heva ve heves düşmanı, ${ }^{33}$ dünya işlerine kendilerini kaptıranların ibadet ve ahiret işlerini ihmal edeceğini düşünen zahit bir şahsiyettir. ${ }^{34}$

Eserde Kün-Toğdı Hakan, adaletle yönetme görev ve sorumluluğu olduğunun bilincinde bir yönetici olarak, yönetimin esasları hakkında bilgi edinmek isteyen bir şahsiyettir. Yusuf Has Hacib, değerlere dayalı yönetimin sırlarını ağırlıklı olarak Hakan'ın soru ve düşüncelerinin merkezde olduğu diyaloglar üzerinde bizlere sunmaktadır. Eserde Hakan'ın Ay-Toldı'ya, onun vefatı sonrasında Ögdülmiş ve Odgurmış'a yönelttiği sorular ile fikri aydınlanmaya açık bir kişiliğe sahip olduğu anlaşılmaktadır. Zikredilen kişilerin Hakan'a verdikleri cevaplar doğrultusunda bu kişilerin aslında bilge kişiler oldukları ortaya çıkmaktadır. Eserde Ay-Toldı karakteri, devletin adalet üzere ayakta kalabileceğini sergilerken, Ögdülmiş karakteriyle de devlet işlerinde adaletin tecellisi için akıl ve bilginin gösterdiği yoldan ayrı hareket edilmemesi gerekliliğine işaret edilmektedir. İnandığı manevi değerlerin toplum dışında kalarak en iyi şekilde yaşanacağını düşünen Odgurmış

\footnotetext{
${ }^{23}$ Hacib, Kutadgu Bilig, b. 674-678.

${ }^{24}$ Hacib, Kutadgu Bilig, b. 690, 697-798.

${ }^{25}$ Hacib, Kutadgu Bilig, b. 763.

${ }^{26}$ Hacib, Kutadgu Bilig, b. 1153.

${ }^{27}$ Hacib, Kutadgu Bilig, b. 1566.

${ }^{28}$ Hacib, Kutadgu Bilig, b. 1606.

${ }^{29}$ Hacib, Kutadgu Bilig, b. 1642-1643.

30 Hacib, Kutadgu Bilig, b. 1695-1697.

${ }^{31}$ Hacib, Kutadgu Bilig, b. 1717-1723.

32 Hacib, Kutadgu Bilig, b. 3145-3151, 3327.

33 Hacib, Kutadgu Bilig, b. 3164.

${ }^{34}$ Hacib, Kutadgu Bilig, b. 3340, 3441.
} 
karakteri ise aslında devlet yönetiminde görev ve sorumluluk almanın hesap verebilirlik gerektirdiğinin önemine dikkatleri çekmektedir. Devlet görevlilerinin bir taraftan yönetilenlerin hak ve hukuklarını gözetme sorumlulukları olduğunun, bunun yanı sıra dini mükellefiyetlerini ihmal etmemeleri gerektiğinin altını çizmektedir. Yusuf Has Hacib, bu karakter aracılığıyla dünyanın geçici olduğunu, bu nedenle yönetim işleri yerine getirilirken dünya ve ahiret dengesinin göz ardı edilmemesi gerektiğini okuyucusuna hatırlatmaktadır.

\subsection{Kutadgu Bilig'in Temel Bölümleri}

Kutadgu Bilig, beş bölümden oluşmaktadır. Birinci bölümde mensur mukaddime, ikinci bölümde manzum mukaddime, üçüncü bölümde babların fihristi, dördüncü bölümde esere konu ana metin, beşinci bölümde ise ekleme üç metin yer almaktadır.

"İlk bölümde yer alan düz yazı girişin kim tarafından eklendiği bilinmemektedir". ${ }^{35}$ Müellif bu bölüme; "besmele" ile başlamakta, Allah'a hamd ve şükürle Hz. Muhammed Mustafa (s.a.v) ve değerli sahabelerine selam ve dua ile bir girizgâh yapmaktadır. Müellif, eserin Çin bilginlerinin örnekleriyle bezendiğini, Maçin âlimlerinin şiirleriyle donatıldı̆̆ını ifade etmektedir Bu çerçevede metinde, Çin ve Maçin âlimleri ve bilginlerinin tümünün Meşrik vilayetinde, bütün Türkistan illerinde, Buğra Han dilinde, Türk lügatince bu eserden daha iyisinin hiç kimse tarafından tasnif kılınmadığ ifade edilmektedir. Bu metinden hareketle eserin, son derece sanatkârca ve görkemli şekilde kaleme alınmış olduğu, ulaştığı coğrafyalardaki bilginler tarafından genel kabul gördüğü ve esere değişik ad ve lakaplar verildiği belirtilmiştir. Bu bölümde ayrıca, eserin müellifinin Balasagun doğumlu ve günahtan sakınan bir kişi olduğu, kitabını Kaşgar ilinde tamamlayıp Meşrik Meliki Tavgaç Buğra Han'a sunduğu, onun da eseri değerli bularak yazara "Has Hacibliğini" (başdanışmanlığı) verdiği ifade edilmektedir. Eserin dört temel üzerine (adalet, devlet, akıl ve kanaat) kurgulandığı ve aşağıda bahsedileceği üzere her birine Türkçe bir ad verildiği de yine bu bölümde bahsedilmektedir."36

İkinci bölümde, ilk bölümde de olduğu gibi Allah'a hamd, Hz. Peygambere ve değerli arkadaşlarına dua ile başlamaktadır. Müellif Yusuf Has Hacib, bu bölümde yazdığı eserin bir bilgi denizi olduğunu, Meşrik meliki, Maçinliler beyi ve ayrıca bilgili, anlayışlı dünyanın önde gelen kişileri tarafından eserin beğenildiğini, hazine olarak muhafaza ettiklerini ifade etmiştir. Bu bölümde, eserin yazıldığı dilden; her kent, ülke veya sarayda esere ayrı ayrı ad verildiğinden; kitabın herkese ve daha çok kentleri yöneten meliklere yararlı olduğundan bahsedilmektedir. Eserde yer alan konulara, eserde yer alan isimlere,

\footnotetext{
35 Çakan, "Sunuş", Xİ.

${ }^{36}$ Hacib, Kutadgu Bilig, 3-4.
}

Journal of Analytic Divinity, https://dergipark.org.tr/tr/pub/jad Volume $4 / 2$ 
temsil ettikleri unsurlara değinen bu bölüm, okuyucusundan dua talebi ve Allah'tan bağışlanma talebi ile tamamlanmaktadır.

"Babların fihristi" başlıklı üçüncü bölümde, eserde detaylıca işlenen konu başlıklarının bir dizini oluşturulmuştur. Eserin dördüncü bölümü olan asıl metinde, temel kavramlar ana karakterler tarafından tartışılmakta, devlet yönetimi esasları ve devlet-halk ilişkileri ele alınmaktadır. Bu bölüme esas temel kurguya aşağıda yer verilecektir.

Eserin beşinci bölümünde yer alan ekli üç kısa alt bölümün birincisinde müellif, gençliğini boşa geçirdiğinden bahisle Allah'tan bağışlanma dilediğini ifade etmektedir. Müellif ikinci kısa bölümde; vefalı kimsenin kalmadığından, halkın bozulduğundan, iyilerin ve iyi törenin kalmadığından bahsetmektedir. Eserin üçüncü kısa bölümünde ise; bilginin önemine, eserin hazırlanma süresine değinilmekte, dünyanın geçici olduğundan bahisle Allah'tan bağışlanma dilenerek Hz. Peygamber ve arkadaşlarına dua edilmektedir.

\subsection{Temel Karakterler Bağlamında Eserin Konusu}

Yukarıda özellikleri bahsedilen Hakan Kün-Toğdı, il işlerini kendisi düzenlemektedir, ancak bütün halkın işini tek başına yapamayacağından kendisine yardım edecek seçkin kişi/-lere ihtiyaç duymaktadır. Zira üstlendiği "adaleti sağlama" görevini tek başına gerçekleştirmesi zordur. Hakan'ın ününü duyan ve onun hizmetinde çalışmak isteyen Ay-Toldı Hakan'a ulaşır. Hakan, yaptığı mülakat sonrasında onu uygun görerek hizmetine alır ve "vezirlik" vazifesini verir. Yönetim işinde Hakan’a yardım ederek bütün işleri yoluna koyan Vezir, zamanla hastalanır ve ölmeden önce bir vasiyetname yazarak Hakan'a iletmek üzere oğlu Ögdülmiş'e verir. Vasiyeti okuyan Hakan, vezirin oğlunu hizmetine alarak yetiştirir ve töreyi öğretir.

Hakan, Ögdülmiş'in görev yükünü azaltmak üzere vakti geldiğinde onun yerini doldurabilecek birisinin olup olmadığını araştırmasını ister ve sonuçta aradığı erdemlere sahip "Odgurmış" adında bu dünyadan yüz çevirip ibadet için dağa giden bir şahsın varlığından haberi olur. Hakan, Ögdülmiş aracılığıyla bu şahsa mektup gönderir ve yönetim işinde kendisine yardımcı olmasını ister. Ancak, bir cevabi mektupla talebinin kabul görmediği kendisine ifade edilir. Hakan'ın talebinde israr ettiği ikinci mektubuna da dünyanın geçiciliğinden bahisle olumsuz cevap verilir.

Aradan zaman geçince Hakan, aynı şahsı bu defa kendisine öğüt vermesi için davet eder ve nihayetinde görüşme talebi kabul edilir. Odgurmış, Hakan'la görüşme sonrası tekrar dağa döner.

Ögdülmiş, zamanla yaşlandığını ve ölümünün yaklaştığını düşünüp Odgurmış'1 ziyarete gider. Ziyarette, dünya işlerinden ahiret işlerine fazla zaman ayıramadığından ve

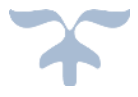


ömrünün sonuna yaklaştığından bahisle görüşünü ister. Odgurmış görüş olarak; onun "ile" yararlı olduğunu, Allah'ın kendisine verdiği iyilikleri bırakmamasını, aksi halde liyakatsiz birinin görevi devralması halinde halka zarar gelebileceğini ifade eder.

Odgurmış'ın zamanla hastalanması üzerine Ögdülmiş onu ziyarete gider ve hasta halinde gördüğü rüya üzerine karşlıklı rüya yorumu yaparlar. Ögdülmiş'in bir sonraki ziyaretinde ise bu defa Odgurmış vefat etmiştir. Ögdülmiş, Odgurmış'ın nasıl vefat ettiği, vasiyeti ve ondan kalanlar hakkında Hakan'a bilgi verir. Ögdülmiş, toparlanması sonrasında yine işinin başına döner ve çalışmalarına devam eder.

\section{Kutadgu Bilig'de Etik Yönetim Gerekliliklerine Dair}

"Etik" kavramıla ilgili muhtelif tanımlar yapılmaktadır. Bu tanımlardan birisine göre; “Etik, kişinin davranışlarına temel olan ahlak ilkelerinin tümüdür. Başka bir ifade ile etik, insanlara "işlerin nasıl yapılması gerektiğini" belirlemede yardımcı olan rehber değerler, ilkeler ve standartlardır". ${ }^{37}$ Etik değer ve ilkelerin hayata geçirilmesi, bir takım yönetim yaklaşımlarının sistemli olarak uygulamaya konulmasını gerektirmektedir.

Kamu yönetiminde kamu hizmetlerinin üretim ve sunumunda rol alan bütün görevlilere görev ve sorumlulukların yerine getirilmesinde hangi davranışların "doğru" olduğu ve hangi davranışların "yanlış" olduğu noktasında gerekli "rehberliğin" sağlanması temel bir önceliktir. Kamu idaresi çalışanlarının istihdamında etik değer odaklı politika ve yönetim yaklaşımlarının geliştirilmesi de kamuda etik anlayışın "kamu görevlileri" unsuru yönüyle güçlendirilmesine katkıda bulunacaktır. Kamuda etik yönetimin güçlendirilmesinin bir diğer sacayağı ise etik davranışın teşvik edilmesi ve etik dışı davranışla mücadele edilmesi bağlamında gerekli izleme ve kontrol politikalarının tanımlanarak uygulamaya konulmasıdır.

Çalışmanın giriş başlığında değinilen "OECD Kamu Dürüstlüğü” yaklaşımına konu temel ilkeler de dikkate alınarak Kutadgu Bilig'de öngörülen etik yönetim gereklilikleri; "etik rehberlik", "çalışan yönetimi ve uygulamaları" ve "etik izleme ve kontrol" gibi temel yönetim işlevlerinden yararlanılarak analiz edilip değerlendirilecektir. Yapılacak analiz ve değerlendirme için öngörülen bu çerçeve, aynı zamanda OECD'nin geçmiş yıllarda tarif ettiği "etik altyapı" mantıksal çerçevesi ile de uyum gösterecektir. ${ }^{38}$.

\subsection{Kutadgu Bilig'de Etik Rehberlik}

Kamu yönetiminde etik rehberlik, "kamu hizmetlerini üreten ve sunan kamu görevlilerine ilişkin beklenen etik davranış kurallarının tanımlanmasını; yöneticilerin etik

37 T.C. Başbakanlık Kamu Görevlileri Etik Kurulu, Etik Rehberi, (Ankara, 2012), 11.

38 Organisation for Economic Co-operation and Development (OECD), Public Sector Integrity, A Framework For Assessment, (Paris: OECD Publishing,2005), 33.

Journal of Analytic Divinity, https://dergipark.org.tr/tr/pub/jad Volume $4 / 2$ 
liderlik uygulamaları sergilemesini; kamu görevlilerine etik eğitimlerin verilmesini ve etikle ilgili danışmanlık hizmeti sunulmasını gerektirmektedir". 39

Etik kod; "etik değerler, ilkeler ve davranış kurallarının yazılı ifade edilme yöntemidir ve davranışa rehberlik etmeyi sağlar". ${ }^{40}$ "Etik yönetim sistemi genellikle etik kodlarla başlamaktadır. Bu düzenlemeler, kamu görevlilerinin uymaları beklenen prensipler dizisi ya da davranış şekillerini ele alır. Bu düzenlemeler, etikle ilgili diğer unsurların oluşturulmasına da zemin sağlarlar". ${ }_{41}$ Yukarıda belirtilen ana karakterlerin ve eserde adları geçen yardımcı karakterlerin konuşmaları incelendiğinde, söz konusu konuşmalarda devlet yönetiminde yöneticiler dâhil kamu görevlilerinin uyması gereken etik değer odaklı davranış standartlarına yer verildiği anlaşılmaktadır.

Kutadgu Bilig'de ele alınan temel değerlerden bazıları şunlardır: Adaletli olmak, doğruluk üzere hareket etmek, akıllı ve tedbirli davranmak, hakları gözetmek, alçak gönüllü ve mütevazı olmak, tamahkâr olmamak, edepli olmak, cömert olmak, liyakate önem vermek, tedbirli davranmak vb. Eserde söz konusu değerlere yapılan atıflardan bazılarını aşağıdaki şekilde ifade edebiliriz:

- Devlet yöneticisinin devletin kalıcılığı için adil olması ve halkın güçlüklerini gidermesi gerekmektedir; 42

- Devlet yöneticisi devletin uzun ömürlü olması için doğru olmalı ve töreyi doğrulukla yapmalıdır; 43

- Vezir, halkına karşı vefalı, ${ }^{44}$ edepli, gözü tok olmalı, mal hırsına düşmemeli, ${ }^{45}$ doğru tavırlar sergileyerek halka adil davranmalıdır; 46

- Kumandan, doğru sözlü ve sözleri uyumlu olmalı, ${ }^{47}$ düşman hatlarını yarıp geçebilmek üzere sabırlı olmalı, askeri şevke getirebilmek için kararlı olmalıdır;48

- Hacib olunduğunda rüşvet alınmamalı, yoksul, dul ve yetimlerin istekleri dinlenilmelidir; 49

- Kapıcıbaşı, Hakan'a tam bağlılıkla hizmet etmelidir;50

\footnotetext{
${ }^{39}$ Yaşar Uzun, “Kamu İdarelerinde Etik Yönetim Altyapısı ve Değerlendirilmesi”, Ombudsman Akademik 6 (Ocak - Haziran 2017), 111.

40 EUROSAI Task Force on Audit\&Ethics (EUROSAI TFAE), "Supporting SAI To Enhance Their Ethical Infrastructure-Part II Managing Ethics ln Practice- Analysis" (Erişim 12.07.2020), 17-18

${ }^{41}$ OECD, Public Sector Integrity, A Framework For Assessment, 80.

42 Hacib, Kutadgu Bilig, b 1435.

${ }^{43}$ Hacib, Kutadgu Bilig, b 5170.

${ }^{44}$ Hacib, Kutadgu Bilig, b 2195.

45 Hacib, Kutadgu Bilig, b 2199-2200.

46 Hacib, Kutadgu Bilig, b 2208.

47 Hacib, Kutadgu Bilig, b 2324.

48 Hacib, Kutadgu Bilig, b 2328.

49 Hacib, Kutadgu Bilig, b 4144.

${ }^{50}$ Hacib, Kutadgu Bilig, b 2529.
} 
- Elçi; gözü tok ve gönülden yöneticiye bağlı, güvenilir ve dürüst biri olmalıdır; ${ }^{51}$

- Katip olunduğunda sir bilgi ifşa edilmemelidir;52

- Hazinedar, hesaplarla ilgili olarak uyanık olmalı, devlet malının sayılı kaydını tutmalıdır. ${ }^{53}$

Eserde yöneticinin hizmetlilerle, kara halkla (yüce halkla), Alevilerle, bilge ve bilginlerle, otacılarla, büyücülerle, düş yoranlarla, yıldızcılarla, şairlerle, tarımcılarla, satıcılarla, hayvan yetiştirenlerle, zanaatkârlarla ve yoksullarla ilişkilerinde uyulması gereken kurallara da rastlanmaktadır. Örneğin; halka karşı yumuşak dilli olunmalı, istekleri karşılanmalı, bunlara çok söz sarfetmeden gerekli sözü sakınarak söylemelidir; ${ }^{44}$ yönetici, her iki dünya iyiliği için bilge ve bilginlerle görüşmeli, iyilikle muamele etmeli, onlar1 sevmelidir ${ }^{55} \mathrm{vb}$.

Yukarıda değinilen örnekler ve eserin bütününde yapılan konuşmalar dikkate alındığında eserin, kendi mantık çerçevesi bağlamında (eserde öykülendirme şeklinde geçen olaylar zinciri dışında) bir etik kod düzenlemesi mahiyeti taşıdığı düşünülmektedir. Yusuf Has Hacib'in, ahlaki değerlere önem veren bir toplum yapısının oluşumunda öncelikle toplumu yönetenlerin bu değerlere sahip çıkmalarını, benimsemelerini ve yaşamalarını önemsediği unutulmamalıdır. Bu nedenle, eserinde başta yöneticiler olmak üzere devlet görevlilerinin sahip olmaları gereken değer odaklı vasıflara detaylıca yer vermiş, örnekleri yukarıda görüldüğü üzere görevlerini yerine getirirken uymaları gereken davranış kurallarına referanslar yapmıştır. Yusuf Has Hacib'in eserinde izlediği bu yaklaşım, günümüz kamu yönetimlerinde uyulması gerekli davranış kurallarının yazılı hale getirilmiş şekli olan etik kodlara duyulan ihtiyaca da karşılık gelmektedir.

Etik değerlerin kavranması ve benimsenmesi için söz konusu değerlerin eğitim ve öğretim aracılığıyla kazandırılması ve kamu görevlilerinin bu yolla yetiştirilmesi gerekmektedir. Devlet yöneticilerinden beklenen davranış kurallarının tanımlanmasının devlet yönetiminde tek başına ahlakiliği sağlamada yeterli olmayacağını düşünen Yusuf Has Hacib, söz konusu kuralların benimsenmesi ve gönüllü olarak uygulanması gerektiğini düşünmektedir. $\mathrm{O}$, bunun eğitim aracılığıyla sağlanabileceğine inanmaktadır. Bu noktadan hareketle Kutadgu Bilig'e bakıldığında etik değerlerin sunulmasında devlete ve özellikle aileye önemli görev ve sorumluluklar atfedildiği gözlemlenmektedir. Hacib'e göre, dürüst kamu görevliliğine giden yol, çocuk küçükken aile içerisinde verilecek eğitimlerden başlamaktadır. Buna göre, oğul ve kız doğduğunda onlara evde eğitim verilmesi gerektiğinin, her iki dünyada yararının olması için oğula ve kıza edep ve bilgi öğretilmesinin, mal sahibi olması için oğula bütün erdemlerin tam olarak öğretilmesi

\footnotetext{
51 Hacib, Kutadgu Bilig, b. 2607.

52 Hacib, Kutadgu Bilig, b. 4146.

53 Hacib, Kutadgu Bilig, b. 2769, 2772.

54 Hacib, Kutadgu Bilig, b. 4320-4335.

55 Hacib, Kutadgu Bilig, b. 4341-4354.
}

Journal of Analytic Divinity, https://dergipark.org.tr/tr/pub/jad Volume $4 / 2$ 
gerektiğinin altı çizilmektedir. ${ }^{56}$ Böylece ahlaki duyarlılığa sahip bireyler yetiştirerek ahlaklı bir toplum oluşumuna katkı verilecek, diğer taraftan da bu bireylerden devlet yönetiminde görev alanlar sayesinde kamu yönetimi değerlerine sahip çıkan devlet yönetici ve görevlilerinin çoğalmasına destek sağlanacaktır.

Hacib, eğitimlerin hayat boyu sürmesi gerektiğini düşünerek, kişilere aile içerisinde verilecek eğitimlerin yanı sıra devlet kademelerinde görev alındığında verilecek eğitimleri de önemsemektedir. Bu kişiler aile ortamında edindiği bilgi ve görgüye ilaveten devlette görev aldıkları eğitimlerle devlet işlerinin yerine getirilmesinde izlenecek yol ve yöntem ve adap esaslarını öğrenmiş olacaklardır. Bu nedenle, kamu görevlisi olacak kişinin küçükken devlette hizmete başlayarak töre ve usul öğrenmesi, davranışlarını düzgün kılmayı başarması, edepli olmayı, uysal olup gönlünü ve dilini kontrol edebilmeyi öğrenmesi de bir eğitim yöntemi olarak eserde yerini almıştır.

Eserde, ana ve tali karakterlerin konuşmalarında etik değerleri yücelten ve hatırlatan, kimi yerde öğreten sözlerin sarfedildiği de görülmektedir. Bu durum bizlere etik eğitimlerin günümüz uygulamasıyla mutlaka sınıf ortamında olmasını gerektirmediğini, yönetici ve çalışanların aralarında söz konusu değerlere sık sık vurgu yapma şeklinde nasihate dayalı didaktik yaklaşımların da uygulanabileceğini anlatmaktadır. Bu şekil bir yaklaşımın, etik değerlerin benimsenmesinde etkili olacağı, etik değerleri gündemde tutarak kamu işlerinde hatırda tutulmasını teşvik edeceği de eserin bizlere işaret ettiği önemli bir husustur.

Etik eğitimlerle ilgili eserde değinilen diğer bir hususta kişinin bu alanda yazılmış eserleri okuyarak söz konusu değerler hakkında gerekli bilginin edinilmesidir. ${ }^{57} \mathrm{Bu}$ noktadan bakıldığında eserde etik eğitimlere ihtiyaç duyulduğu ve bunun temini için aile bünyesinde ve devlet içerisinde gayret sarfedilmesi gerektiği sonucunu çıarmak mümkün olacaktır.

Yöneticilerin değerlere dayalı bir yönetim için etik liderlik sergileme gereklilikleri de eserde değinilen önemli bir konudur. Bilindiği üzere etik liderler, "karakterleriyle, dürüstlükleriyle, etik bilince sahip olmalarıyla, ortak ihtiyaç ve çıkarlara hizmet etmeleriyle, örgütsel başarı ve performans açısından etik dışı olumsuz gelişmelerin karşısında duran kişilerdir. Etik liderler, kişisel veya politik çıkarlar için değil, diğer bireylerin yararına olacak şekilde çalışırlar. Evrensel değerler tarafından belirlenen etik yaşama özgü doğru şeyleri yapmak için çaba gösterirler ve bu konuda standartlar belirleyip

\footnotetext{
56 Hacib, Kutadgu Bilig, b. 1228, 4504-4508.

57Hacib, Kutadgu Bilig, b. 2698-2699.
} 
çalışanları da bu standartlara uyma konusunda teşvik ederek onları bu konuda sorumlu tutarlar. Ayrıca etik davranma hususunda çalışanlarına örnek olmaya çalışırlar" ${ }^{58}$

Yusuf Has Hacib, etik yönetim anlayışına uygun şekilde devlet yöneticisinin ahlaki erdemlere sahip bir kişi olarak liderlik vasıflarını sergilemesi gerektiğini düşünmektedir. Yönetilenlerin sorunlarını çözerek mutlu ve huzurlu olmasını sağlamanın yolu, onlara toplum olarak beraber ilerledikleri yolda doğruluğu ve dürüstlüğü telkin edecek, davranışlarıyla onlara doğru yolu işaret edecek güçlü liderlere sahip olmaktan geçmektedir. $\mathrm{O}$, eserinde yer verdiği liderlik davranış örnekleriyle yöneticilerin dürüst toplum ve dürüst kamu yönetiminin inşasında kilit konuma sahip olduklarını asırlar öncesinden bizlere ifade etmektedir. Kutadgu Bilig'de devlet yöneticisinin özellikleri sayılırken "etik liderlik" işaretleri olabilecek şu örnek tespitlere değinilmektedir: Bilgili ve akıllı olan yönetici, halkına yardım için siyaset izler. Yürekli bir kişiliğe sahip olan yönetici, kötüye ve düşmana karşı sağlam duruş sergiler. Kendi yönetiminde akla ve bilgiye önem vererek akıllıları hizmete çağırır ve bilgilileri yükseltir. Devlet istihdamında değer odaklı vasıfları taşıyanları aramak ve böylesi kişilikleri istihdam etmek yöneticinin temel özelliklerindendir. ${ }^{59}$ Kutadgu Bilig' de liderin değerler odaklı öğütler verip durması halinde yapılan yasaların tümünün iyi olacağına ve Allah'ın yardımıyla devletin payidar kalacağına işaret edilmektedir. ${ }^{60} \mathrm{Bu}$ yönüyle yöneticinin değerlere dayalı söylem geliştirmesi ve bunu devlet görevlilerine ve işleyişine aktarması etik liderlikle ilgili önemli ipuçları sağlamaktadır. Eserde, yönetici davranış ve tutumlarının halk üzerindeki etkisi değerlendirilirken davranışlarını düzelten beylerin temiz insanlarla işleri yola koyacağına vurgu yapılmaktadır.61 Devlet yöneticisi, hizmetlerin sunulmasında yararlı işler üretilmesine ve tam bağlllığa; hizmet karş1lığı ücret ödenmesine ve dürüstlüğe önem vermektedir. ${ }^{62} \mathrm{O}$, her türlü işte hizmetlileri değer odaklı olarak sınamakta ${ }^{63}$ ve hizmetlisine verdiği değeri gösterip bağlılıkla çalışmalarını teşvik etmektedir. ${ }^{64}$ Hakan; yönetici olarak her işinde doğruluk üzere hareket ettiğini, ${ }^{65}$ yasa karşısında herkesi eşit tuttuğunu, ${ }^{66}$ güneş misali halka karşı söz ve tavrının bir olduğunu, ${ }^{67}$ beyin iyi olması durumunda, halkın da düzgün olacağını ve zenginleşeceğini 68 ifade etmektedir. Eser uyarınca, halkın başındaki iyi olursa onun bütün işçileri de iyi olacaktır. Eğer beylerin kendileri iyi olursa, halk1 zenginleştirecekler ve dünyayı düzelteceklerdir. ${ }^{69}$

\footnotetext{
58İsmail Bakan - İnci F. Doğan, Liderlik: Güncel Konular ve Yaklaşımlar (Ankara: Gazi Kitabevi, 2013), 77-78.

${ }^{59}$ Hacib, Kutadgu Bilig, b. 407-419.

${ }^{60}$ Hacib, Kutadgu Bilig, b. 6265-6266.

${ }^{61}$ Hacib, Kutadgu Bilig, b. 5949.

62 Hacib, Kutadgu Bilig, b. 595-597.

63 Hacib, Kutadgu Bilig, b. 629.

${ }^{64}$ Hacib, Kutadgu Bilig, b. 763.

65 Hacib, Kutadgu Bilig, b. 809.

66 Hacib, Kutadgu Bilig, b. 817-818.

${ }^{67}$ Hacib, Kutadgu Bilig, b. 828.

68 Hacib, Kutadgu Bilig, b. 887, 895.

${ }^{69}$ Hacib, Kutadgu Bilig, b. 871-895.
}

Journal of Analytic Divinity, https://dergipark.org.tr/tr/pub/jad Volume $4 / 2$ 
Öte yandan kamu görevlileri etik değer, ilke ve kuralların yorumlanmasında da yardıma ihtiyaçları olabilecektir. Bu noktada "etik danışmanlık" fonksiyonunu üstlenecek kişi/kurum/birim yapılarının varlığı önemli olacaktır. Etik kodların ve eğitimlerin gerçek hayattaki bütün durumlara hitap etmesinin mümkün olamayacağı ve bir danışılma, görüş alma merciine ihtiyaç olacağı aşikârdır. Devlet yönetiminde herkesin ayrı bilgi, deneyim ve tecrübeye sahip olacağı, her alanda uzman olamayacağı gerçeğinden hareket eden Yusuf Has Hacib, devlet yönetiminde görev alanların karşılaştıkları meselelerde bir bilene danışmalarının zorunlu olacağını öngörerek etik alanı da kapsayacak şekilde "danışmanlık müessesesinin" gerekliliğine eserinde yer vermektedir. Hacib’e göre devlet işlerinde danışmak dini hükümlerin de bir gereğidir. Kutadgu Bilig'de etik danışmanlıkla ilgili olarak şu hususların tespit edildiğini ifade edebiliriz: Esere göre hangi iş yapılırsa yapılsın insanlara danışılmalıdır.70 Danışmanlar, akıl ve bilgiye sahip oldukları için atanırlar. ${ }^{71}$ Kendi yararını düşünmeyen insana danışılmalıdır. ${ }^{72}$ Öte yandan eserde kamu görevlisi olmayan Odgurmış' in Vezir Ögdülmiş'e Hakan'ın kendisini görmek istemesi üzerine nasıl davranması gerektiği hakkında tavsiye talep ettiği durumlara da rastlanılmaktadır. ${ }^{73}$ Esere göre; sonunda pişman olmamak üzere her işi yakın bilinen birine danışarak yapmalı, danışmak gerekirse kendi yakınına danışılmalıdır. Kişi işini nasıl göreceğini bilmiyorsa bilen başkasına danışmalı ve danışanın ilgili işe "yararlı" demesi durumunda o işi yapmalı, "yararsız" demesi durumunda ise o işten vazgeçmelidir. Danışmakla kişinin bilgisi genişleyecek ve danışma sonucunda bilgili hareket edildiğinde danışılan iş halledilecektir. ${ }^{74}$ Eserde Hakan'ın farklı özellik ve huyları olan bir halkı nasıl yönetmesi gerektiğine Ögdülmiş'in verdiği cevaplarda bir etik danışmanlık örneği olarak ifade edilebilir. ${ }^{75}$ Hizmetli unvanlarının hangi vasıflara sahip olunması gerektiğini izah eden beyitlerde Ögdülmiş'in bu unvanların gerektirdiği etik değer ve ilkelere dayalı nitelikler hakkında Hakan'a verdiği bilgiler de etik tavsiyeler arasında sayılabilir.

Yukarıdaki açıklamalar ışı̆̆ında, Yusuf Has Hacib'in eserinin günümüz kamu yönetimleri için öngörülen etik rehberlik gerekliliklerine karşılık gelecek unsurları içerdiğini söylemek mümkün gözükmektedir.

\footnotetext{
70 Hacib, Kutadgu Bilig, b. 5659-5660.

${ }^{71}$ Hacib, Kutadgu Bilig, b. 1995.

72 Hacib, Kutadgu Bilig, b. 3493.

${ }^{73}$ Hacib, Kutadgu Bilig, b. 3482-3483.

${ }_{74}$ Hacib, Kutadgu Bilig, b. 5650-5658.

75 Hacib, Kutadgu Bilig, b. 1921-1929.
} 


\subsection{Kutadgu Bilig'de Çalışan Yönetimi ve Uygulamaları}

Doğruluk, dürüstlük gibi değerlerin devlet yönetiminde hayat bulmasının bir boyutu da devlette çalışanların yönetilmesine dair temel politika alanlarının (işe alım, yetiştirme, görevlendirme vb.) etik değer ve ilkeler eksenli olarak düzenlemesi gerekliliğidir. Bu noktadan hareketle çalışmanın konusu olan Kutadgu Bilig'e bir sarf-1 nazarda bulunacak olursak aşağıdaki tespitleri yapmamızın mümkün olduğunu söyleyebiliriz:

Eserde ele alınan işe alım yaklaşımına bakacak olduğumuzda devletin en üst yöneticisi ile devlet görevlilerinin istihdamında "seçkinliğe" dair bir usulün izlendiği anlaşılmaktadır. Söz konusu "seçkinlik", nihayetinde bir "seçme" eylemini ihtiva etmektedir. Bir farkla ki, eserde devlet yöneticisini seçen Tanrı' dır. Tanrı kimi "bey" olarak yaratmak isterse ona önce uygun tavır, akıl verir ve kol kanat gerer. Tanrı kime beylik işini vermişse o kişi “bey" olur ve anasından doğduğunda beylikle doğar. O kişi de görüp öğrenerek hangi işin iyi olduğunu bilir, öğrenir. ${ }^{76}$ Bununla birlikte eserde "bey"de bulunması gereken vasıflara da (iyi huyluluk, alçak gönüllülük, akıllılık, bilgililik, insanlıkla iş görme vb.) değinilmiştir. Eserde, bey'in vasıflarının anlatıldığı beyitlerde "bey" için gerekli erdem ve töreye (kurallara) sahip insanların yükseltilip "bey" olarak atanmasının önerildiğini de hatırlatmakta yarar vardır. ${ }^{77}$ Esere diğer devlet yöneticisi ve kamu görevlileri açısından bakıldığında bunların işe alınmasında etik değer ve ilkelere öncelik verildiği ve işe alınanların sınanması gerektiği ifade edilmektedir.78 Söz konusu beyit örneklerinden de anlaşılacağı üzere işe alımlarda işin gerektirdiği değerler, bilgi, beceri ve deneyimler temel kriterler olarak belirlenmiştir.

Eserde işe alımla ilgili gereken vasıfların araştırılmasına yönelik bazı esasların da önerildiği anlaşılmaktadır. Bu esaslardan bazıları işe alım öncesi aşamalara aittir, bazıları ise işe alındıktan sonraya aittir. İşe alım öncesinde şahsın iş gerekliliklerine uyup uymadığını belirlemeye yönelik olarak örneğin, tanınmayan birisini tanımak için tanıdıklarına sorma gerekliliğinden ${ }^{79}$ bahsedilmektedir. İşe alım sonrasında ise iş vasıfları gerekliliklerine yönelik hizmetlinin sinanması da ${ }^{80}$ eserde bir gereklilik olarak vurgulanmaktadir.

Eserde işe alımla ilgili Ay-Toldı ile Has Hacib ve Ay-Toldı ile Hakan arasındaki görüşmeler de işe alımlarda "mülakat" usulünden yararlanılması gerektiğini bizlere anlatmaktadır. Yapılacak mülakatlarla, işe başvuranın sözleri, duruşu, görünümü, tavırları itibariyle devlet yönetiminde gerekli vasıflara uygunluğunun tespit edilebileceği eserde temel karakterler üzerinden ifade edilmektedir. ${ }^{81}$

\footnotetext{
76 Hacib, Kutadgu Bilig, b. 1932-1934.

77 Hacib, Kutadgu Bilig, b. 2165.

78 Hacib, Kutadgu Bilig, b. 1755-1756, 2927-2932, 2238, 2524.

79 Hacib, Kutadgu Bilig, b. 2251.

80 Hacib, Kutadgu Bilig, b. 619.

81 Hacib, Kutadgu Bilig, b. 523-569, 595.
}

Journal of Analytic Divinity, https://dergipark.org.tr/tr/pub/jad Volume 4/2 
Netice itibariyle Yusuf Has Hacib, halkın erdemli bir halk olması isteniyorsa onu yönetenlerin de o erdemlere sahip kişiler olması gerektiğini düşünmektedir. Bu nedenle Yusuf Has Hacib, devlette istihdam edilecek kişilerin kamu hizmetinin gerektirdiği değerlere uygun kişiler olması gerektiğinin altını çizmekte, bu vasıflara sahip kişilerin sinamaya tabi tutularak seçilmesinin zaruri olduğunu bizlere hatırlatmaktadır. Böyle yapılmaması durumunda ise işe alınanların halka ve yöneticiye, dolayısıyla devlet yönetimine zarar vereceklerini düşünmektedir. Bu yönüyle bakıldığında eserin günümüz etik yönetim anlayışında öngörülen değer odaklı işe alım politikalarına karşılık gelen bir yaklaşımı içerdiğini söylemek mümkün gözükmektedir.

Kamu hizmetlerinin liyakatli kişiler aracılığıyla üretilmesi ve sunulması kamu hizmetinden yararlanacakların temel beklentisidir. Bu nedenle, kamuda görev alan kişilerin hizmet gereklerine uygun şekilde yetiştirilmeleri de kamu itibarının korunması açısından üzerinde durulması gereken önemli bir politika alanıdır. Yusuf Has Hacib, devlette istihdam eden görevlilerin hizmetlerin sunulacağı halka yararlı olabilmeleri açısından eğitimi önemsemektedir. Eserde, yöneticinin işe alınan görevlileri yetiştirme bağlamında sorumluluğuna atıfta bulunmaktadır. Hakan'ın Vezir Ay-Toldı'nın vefatı sonrasında onun oğlu Ögdülmiş'i hizmete alma konusundaki düşünceleri, okuyucuya hizmetlinin yetiştirilmesine dair esaslar hakkında bir fikir vermektedir. Buna göre Hakan, hizmetlisini adam olmaları, yararlı insan olmaları açısından yetiştirmeyi uygun görmektedir. ${ }^{82}$ Zira bu tür kişinin/-lerin görevin gerektireceği vazifeleri yerine getirecek bir temayülleri vardır. Yetiştirilecek kişilerin (doğuştan insan ve yükselecek olanın) küçükken (veya adaylık döneminde) bütün işaretleri bulunmaktadır. ${ }^{83}$ Vezir Ay-Toldı'nın Hakan'a vasiyetnamesinde de bahsedildiği üzere, devlet yöneticisi küçükken hizmete girenlere (günümüz tabiriyle adaylık hakkını kazanan görevlilere) erdem ve meslek için gerekli bilgiyi öğretmeli, düzgün tavırlara sahip olmalarını, hizmete yararlı olmalarını sağlamalıdır. ${ }^{84} \mathrm{Bu}$ çerçevede eserin etik yönetim için elzem olan profesyonel işgücünün yetiştirilmesi noktasında bir bakış açısını okuyucusuna sunduğunu ifade edebiliriz.

Doğru adamı doğru yerde görevlendirmek günümüz etik yönetim anlayışının bir gereğidir. Yusuf Has Hacib’e göre, halka faydalı hizmet sunabilmek üzere yöneticinin hangi işe hangi vasıfta çalışan görevlendirilmesi gerektiğini bilmesi ve buna göre görevlendirme yapması gerekmektedir. Kamu görevlisinin görevlendirilmesi noktasında esere bakıldığında şu tespitlerin yapıldığı anlaşılmaktadır: Küçükken/adayken yetiştirilen hizmetlilerin hangi göreve getirilecekleri işle ilgili sahip olduğu vasıflar dikkate alınarak yönetici tarafından belirlenir. Örneğin; hizmetli zeki ve tutarlı olursa arz görevlisi olur;

\footnotetext{
82 Hacib, Kutadgu Bilig, b. 1627.

83 Hacib, Kutadgu Bilig, b. 1646-1648.

84 Hacib, Kutadgu Bilig, b. 1489-1490.
} 
attığını vurursa ok yaycısı olur, doğru tavırlıysa mühürdar olur; tavrı, davranışı temiz ve iyi görünümlü ise saki olur; yazı, sayı bilirse hazinedar olur; akıl, anlayış varsa katip olur vb. ${ }^{85}$ Devletle ilgili unvanlara küstah ve bilgisiz kişiler yerleştirilmemelidir. ${ }^{86}$ Hizmetli önce fiilleri ve kusurları yönüyle sınanmalı ve sonra aklının dengince işler verilmelidir. ${ }^{87} \mathrm{Bir}$ iş, aynı anda iki kişiye söylenmemelidir, zira işler yapılmadan kalır ve iş bozulur. İşi, iş bilenlere vermek gerekir. Hizmettir diye olur olmaza iş verilmemelidir. Yararlı kişiyi değerli tutarak gerekli işi ona vermelidir. 88 İş, iş bilene, yararlı, doğru ve dürüst olana verilmezse yararsız iş yapılmış olur. ${ }^{89} \mathrm{Bu}$ beyitler, hizmetlilerin (kamu görevlilerinin) görevin veya işin gerektirdiği meziyetlere ve kapasiteye sahip olunarak görevlendirilmelerinin esas olması gerektiğini bizlere söylemektedir.

Bu noktada yukarıda örnekleri verilen görevlendirme yaklaşımları dikkate alınarak eserin, devlet yönetiminde doğru işlerin doğru kişilere gördürülmesi anlayışına uygun bir yaklaşımı öngördüğünü söyleyebiliriz.

Öte yandan çalışanların etik değerlere uygun performans sergilemelerinin kamu yönetiminin etik performansını da güçlendireceği dikkate alınırsa, eserde çalışanların performanslarının yönetilmesine dair esaslara da yer verildiği anlaşılmaktadır. Kutadgu Bilig, halka yararlı bir yönetim sergileyebilmek açısından devlet görevlilerinin kamu hizmetinin gerektirdiği değerlere ve teknik vasıflara uygun şekilde çalışma yapmalarının önemli olduğuna dikkati çekmektedir. Kamu görevlisinin "yararının veya performansının" değerlendirilmesi açısından eserde, çalışanın yapmadığı işin yarının işine ekleneceği; işlerin yı ̆̆ılması nedeniyle devlet işlerinin sürüncemede kalacağı ve halkın mutluluğunun sağlanamayacağı esas olarak belirtilmektedir. ${ }^{90}$ Kişi ile ilgili yapılacak değerlendirmede kişinin yaptıklarının (davranış ve işlerinin) kendisine tanık olması nedeniyle, kişi tarafından ortaya konulacak işlerin nicelik ve niteliği/devlete ve halka yararlılığı yapılacak bir değerlendirmeye esas olacaktır. ${ }^{11}$ Hizmet ederken yanlışlık yapmamaları için yapılan işlerin denetlenmesi gerekmektedir. ${ }^{92}$ Yararlı ile yararsız olanlar bir tutulmamalıdır. ${ }^{93}$ Yararlı kişi değerli tutulmalıdır. ${ }^{94}$

Kamu görevlisinin ücretlendirilmesi/ona bağışta bulunulması yönüyle eser değerlendirildiğinde önce eserde geçen "bağış" kavramının tanımına değinmek yararlı olacaktır. "Bağış" kavramı Türk Dil Kurumu sözlüğünde "bir kimsenin, kuruluşun veya ülkenin aynî ya da nakdi varlıklarını bir başka kişi, kurum veya ülkeye karşılıksız olarak

\footnotetext{
85 Hacib, Kutadgu Bilig, b. 4045-4048.

${ }^{86}$ Hacib, Kutadgu Bilig, b. 4073-4077.

87 Hacib, Kutadgu Bilig, b. 4080.

88 Hacib, Kutadgu Bilig, b. 5533-5539.

${ }^{89}$ Hacib, Kutadgu Bilig, b. 1759-1760.

${ }^{90}$ Hacib, Kutadgu Bilig, b 5502-5504.

91 Hacib, Kutadgu Bilig, b 5810.

92 Hacib, Kutadgu Bilig, b 4185.

93 Hacib, Kutadgu Bilig, b 5532.

94 Hacib, Kutadgu Bilig, b 5539.
}

Journal of Analytic Divinity, https://dergipark.org.tr/tr/pub/jad Volume $4 / 2$ 
devretmesi" şeklinde tanımlanmıştır. Eserde daha çok bu anlamıyla kullanılan "Açıg" yani "bağış" sözcüğü bazı beyitlerde ise "ücret" anlamında da kullanılmıştır. ${ }^{95}$ Eserde düşmana, kurda karşı koyan eratın Hakan'ın bağışlayacağı mal ile sevindirilmesi, yararlarının dengince ağırlanması, mallarının çoğaltılması ve güçlerinin artırılması öngörülmektedir. ${ }^{96}$ Hakan, kılıçla yararlı olan alp atıcıyı, danışmanlığından istifade edilen büyük bilge devlet adamını ve hazineyi dolduran, gelir gideri bilen yazıcıyı ağır tutmalı ve onlara yararlarının dengince değer verip bağışta bulunmalıdır. ${ }^{97}$ Eserde genel anlamda yararlı işlerin, bağlılık ve dürüstlük içinde çalışmanın karşılığının bağış/ücret olduğunun altı çizilmektedir. ${ }^{98}$ Beyitlerde geçen "hizmetine göre" ve "faydalı oldukları nispette" ifadelerinden Yusuf Has Hacib' in ücretlendirme konusunda performansa dayalı bir ücret sistemini benimsediği ve önerdiği kolaylıkla anlaşılmaktadır. ${ }^{99}$

Eser, bulundukları devlet kademelerinde başarılı performans sergileyerek sahip oldukları vasıflar ve deneyimler itibariyle üst görevlerde çalışmayı hak eden veya çalıştırılması gerekenlere dair de yönetim yaklaşımı içermektedir. Kamu görevlisinin yükseltilmesi konusunda eserde etik değer ve ilkeler odaklı esasların benimsendiği anlaşılmaktadır: Kötü, zorba ve acımasız kişinin yükseltilmemesi ve yetki verilmemesi gerekir. ${ }^{100}$ Hizmetlinin akıllı ve bilgili olması durumunda bunların dengince yükseltilmesi beklenir. ${ }^{101}$ Eserde dürüstlükle, işi severek yapmayla ve işi eksiksiz arzu edildiği şekilde yerine getirmekle yükselineceğine vurgu yapılmaktadır. ${ }^{102}$ Yükseltilecek kişinin sınanması, her işinin incelenmesi ve dürüstlüğünün ve bağlılığının tespiti, beye dolayısıyla devlete yararlı görülmesi, ileride işe yarayacak olması, arzu edildiği şekilde hizmet sunması, içtenlikle ve severek hizmet etmesi, iş yönüyle hizmet sunma açısından boşta kalmaması yükseltmede öne çıan kriterler olarak ifade edilmektedir. ${ }^{103}$ Kamu görevlisinin hatalı davranışlarının düzeltilmesi anlayışı olarak esere bakıldığında, hizmet ederken bir şeyde yanlışlık yapılması durumunda cezalandırma, yapılan işleri kontrol etme ve hizmetliyi başıboş bırakmama gibi bir anlayışın öngörüldüğü anlaşılmaktadır. ${ }^{104}$ Yine eserde kişiye değer verip vermemenin de davranış değişikliğine etkisinden bahsedilmekle kötüye değer verilmediğinde halini düzelteceğini, iyiye değer verilmesi halinde ise tavırlarının daha iyi

\footnotetext{
95 Ahmet Vecdi Can vd. "Kutadgu Bilig' de Muhasebe, Ticari Hayat ve Etik ile İlgili Beyitler ve Güncel Yorumu”, Muhasebe ve Finans Tarihi Araştırmaları Dergisi 2 (2012), 72.

96 Hacib, Kutadgu Bilig, b. 5591-5594.

97 Hacib, Kutadgu Bilig, b. 5910-5914.

98 Hacib, Kutadgu Bilig, b. 596.

99 Can, Kutadgu Bilig'de Muhasebe, Ticari Hayat ve Etik İle İlgili Beyitler ve Güncel Yorumu, 73.

100 Hacib, Kutadgu Bilig, b. 5521.

101 Hacib, Kutadgu Bilig, b. 4079.

102 Hacib, Kutadgu Bilig, b. 607-619.

103Hacib, Kutadgu Bilig, b. 1751-1756, 2543-2545.

${ }^{104}$ Hacib, Kutadgu Bilig, b. 4185.
} 
olacağına vurgu yapılmaktadır. ${ }^{105}$ Öte yandan yanlış tavırları düzeltmek açısından kişinin inandığı bir rol modeli kendine ayna tutması, kendisini görmesi için bu aynaya bakılarak tavrını düzeltebileceği de vurgulanan bir husustur. ${ }^{106}$ Eserde disiplin yönetiminde etkinliği sağlamak üzere; kötülerin bastırılması, hoşgörülü davranılmaması, ${ }^{107}$ bir işte öfkeli ve kızgın olunmaması, ceza vermede (hatalı davranışta diğer düzeltici yaklaşımları devreye sokarak) cezanın hemen uygulanmaması gibi yöntemler de hatırlatılmaktadır. ${ }^{108} \mathrm{Bu}$ bağlamda eserin, günümüz etik yönetim anlayışının öngördüğü etik davranışın yönetilmesi kapsamında önleyici, düzeltici ve gerekli durumlarda yaptırım uygulayıcı bir disiplin politikasına karşılık gelen yönetim yaklaşımı içerdiğini ifade edebiliriz.

Bu açıklamalar ışığında Kutadgu Bilig' in, günümüz kamu yönetimleri için öngörülen çalışanların değer odaklı politikalarla yönetilmesi anlayışına karşılık gelecek unsurları bünyesinde barındırdığını söylemek mümkün gözükmektedir.

\subsection{Kutadgu Bilig' de Etik İzleme ve Kontrol Yaklaşımları}

Kamu yönetimlerinde etik anlayışın güçlendirilmesi için yapılacak çalışmaların özünde kamu hizmeti üretim ve sunumunda kamu görevlilerinin etik davranışlarını teşvik etmek ve bu bağlamda etik dışı davranılmasını önleyici tedbirleri almak yatmaktadır. Bu anlamda etik davranışı teşvik edici, etik ihlallerini önleyici, tespit edici ve düzeltici yönetim yaklaşımlarının geliştirilmesi önem taşımaktadır. Etik davranışın izlenmesine ve kontrol edilmesine yönelik geliştirilecek yönetim yaklaşımları bir taraftan etik rehberlik ve çalışan yönetimi politikalarının etkin şekilde uygulanmasına, bir taraftan da kamu yönetiminde etik performansın izlenmesine ve değerlendirilmesine değer katacaktır. Yusuf Has Hacip' de halkın yönetici üzerindeki haklarını elde edip etmediğini, yöneticiden duydukları memnuniyet veya memnuniyetsizliği öğrenmek üzere onların değerlendirmelerinin alınması gerektiğine eserinde yer vermektedir: Hakan, Ögdülmiş'i çağırır ve halkın halini, il gün işini sorar. Buradaki halkın halini sormadan maksat, görev ve ahlaki değerlere odaklı vasıfları itibariyle eserde bahsedilen Hakan hakkında halkın kanaatini öğrenmek, Hakan'ın uygulamalarının halk üzerindeki etkilerini ve bunlardan memnuniyet düzeyini tespit etmektir. Hakan'ın, dolayısıyla beyliğin etik performansını tespit etmeye yönelik yapılan sorgulamada Ögdülmiş'e Hakan adına halkın halini gözlemleme, memnuniyet veya memnuniyetsizlikleri dinleme, duyma, bilgileri alma görev ve sorumluluğunun verildiği anlaşılmaktadır. Vezir Ögdülmiş, halkın halinin nasıl olduğu sorusuna halkın halinin iyi olduğu ve Hakan'a dua edildiği bilgisini vermektedir. 109 Hakan'ın Ögdülmiş aracılı̆̆ıyla

\footnotetext{
105 Hacib, Kutadgu Bilig, b. 5527-5528.

106 Hacib, Kutadgu Bilig, b. 5618-5619.

107 Hacib, Kutadgu Bilig, b. 5227.

108 Hacib, Kutadgu Bilig, b. 5216-5218.

109 Hacib, Kutadgu Bilig, b. 6347-6351.
}

Journal of Analytic Divinity, https://dergipark.org.tr/tr/pub/jad Volume $4 / 2$ 
halkın yönetimi hakkındaki kanaatlerini öğrenmesi, aynı zamanda bir öz değerlendirme çalışması olarak da nitelendirilebilir.

Etik davranışın teşvik edilmesi ve etik ihlallerine zemin hazırlayabilecek riskli durumların takibi de günümüz yönetim anlayışının bir gereğidir. Zira etik davranışın yönetiminde karşı karşıya kalınabilecek muhtemel risklerin önlenmesi, tespit edilip ortaya çıkarılması ve yönetilmesine dair kontrol amaçlı tedbirler, dürüstlüğe dayalı bir kamu yönetimi anlayışının güvence yapı taşlarını oluşturacaklardır. Bu noktadan eser analiz edildiğinde etik davranışı yönetmeye dair "kontrol" amaçlı şu tedbirlerin önerildiğini tespit etmek mümkündür: Devletin uzun yaşaması ve insanların zarar görmemeleri açısından devleti yönetenlerin uyanık olmaları temel bir zorunluluktur. Bunun için gerekli tedbirleri almak, kamuya yararı olmayanlarla ve kötü davranış sergileyenlerle başa çıkmak gerekmektedir. ${ }^{110}$ Yöneticiler; devletin düzeninin korunması için halkın durumu ile ilgilenmeli, düzenin bozulmasına yol açabilecek muhtemel tehlikeleri zamanında sezebilmeli, gerekli tedbirleri alarak uygulamalıdırlar. Öte yandan "aymaz" olmamak ve devlet yönetiminde gerekli tedbirleri almak dinin de bir gereğidir.111 Aymazlıkla devletin düzeni bozulacaktır. Ayrıca yasayı doğru yapıp doğru uygulamak, etik davranışı teşvik etmede ve kamu düzenini korumada önemli bir tedbir unsuru olacaktır. ${ }^{112}$ Bu manada, günümüzde kamu itibarının zedelenmesine yol açabilecek davranışlarla ilgili risklerin yönetilmesi gerekliliğinin Kutadgu Bilig'de karşılık bulduğunu söylemek mümkündür.

Eserde hatalı davranışı ihbar edilmesinde izlenecek yaklaşıma da işaret edilmektedir. Devletin günlük işleyişi sırasında herhangi bir kamu görevlisinin ciddi sonuçlar doğurabilecek hatalı davranışı hakkında yetkililere ihbarda bulunma ihtiyacı doğabilecektir. Bu tür durumlarda, önce hakkında ihbar edilenin konu hakkındaki düşünceleri alınmalı, sonuna dek durum irdelenmeli, soruşturulmalı ve tespitlere göre nihai karar verilmelidir. İhbarcının iddiasının ilk etapta dinlenilmesi, iddianın yalan olup olmadığının araştırılarak ortaya konulması gerekir. Eserde ayrıca, gördüğü densizliklere gözünü yuman devlet görevlisinin kendi başını yiyeceği de ifade edilmektedir. ${ }^{113} \mathrm{Bu}$ açıklamalar, günümüz etik yönetim anlayışı gerekliliklerine de uygun düşmektedir.

Yusuf Has Hacib, etik dışı davranışın önüne geçebilmek için günümüzde öngörülen menfaat çatışmasının yönetilmesi, hediye ve menfaat kabul yasağı gibi konularda izlenecek yönetsel yaklaşıma eserinde yer vermiştir. Hacib'e göre, hizmetli, candan istekli şekilde hizmet sunmalı, kendi yararını düşünmemeli ve tam bir bağlılıkla devletin yararını

\footnotetext{
110 Hacib, Kutadgu Bilig, b. 437-439.

111 Hacib, Kutadgu Bilig, b. 446.

112 Hacib, Kutadgu Bilig, b. 2010-2028.

113 Hacib, Kutadgu Bilig, b. 2510-2511.
} 
istemelidir. ${ }^{114}$ Hep kendi yararını düşünen birisi, bencil bir kişi olacaktır. ${ }^{115}$ İnsanların iyisi kendi yararını bir tarafa bırakıp, başkalarının yararını gözetir.116 Kişi kendi iyiliğinin değil, neticede halkın yararına olması için devletin iyi olmasını istemelidir.117 Akıllı bir yönetici, kendi yararını isteyene bir şey danışmaz, kendi yararını düşünmeyen danışmana danışır. ${ }^{118}$ Devlet görevlisi rüşvet almadan bütün kamu işlerini yerine getirmelidir. ${ }^{119} \mathrm{Bu}$ tespitler ışı ̆̆ında Yusuf Has Hacib' in kamu işlerinde rüşvetin olmamasını ve bireysel çıkarın yerine kamu çıarının önceliklendirilmesini istediğini ifade edebiliriz.

Etik anlayışa sahip bir kamu yönetiminde hak ve hürriyetlerin gözetilmesi, adaletin tecellisi açısından yargı müesseselerine de duyulacaktır. Yusuf Has Hacib, bu ihtiyaca da eserinde yer vermektedir. Hacib'e göre Kadı' nın özenli, temiz, günahtan sakınan ve halka yararlı bir görevli olması gerekmektedir.120 Kadı, doğruluk üzerine hareket etmelidir.121 Yargılama sürecinde davacının işi uzatılmaz, doğrulukla hareket edilerek kesin hüküm verilir. Bu süreçte güçlük çıkarıp dürüstlükten kaçan zorbalara karşı yasa gerekleri uygulanır. Yasanın karşısında evlat, yakın, yabancı, yolcu vb. herkes birdir. Dolayısıyla günümüzde de öngörüldüğü şekilde, kanun önünde herkes eşittir. $\mathrm{O}$, dürüst bir yargılama ve doğru hükme varabilme açısından her tür tedbirin alınmasını öngörmektedir.

Eserde, etik izleme ve kontrol fonksiyonunun bir gerekliliği olarak devletin işleyişinde şeffaflığın sağlanmasına dair muhtelif referanslara da yer verilmektedir: $\mathrm{Bu}$ bağlamda devlet malının kaydedilmesi (2769), devlet hesaplarının tarihi ile beraber tam şekilde tutulması, devlet işlemlerinde yazılı kayda geçilmesi, ${ }^{122}$ bütün işlerin açık ve yerinde yapılması, ${ }^{123}$ devlet hesaplarının denetim ve kontrole hazır tutulması ${ }^{124}$ gibi esasların devlet işlerinde şeffaflıkla ilgili önemli ipuçları içerdikleri anlaşılmaktadır.

Yusuf Has Hacib, etik yönetim için gerekli hesap verebilirlik müessesesinin varlığına duyulan ihtiyaca da eserinde yer vermektedir. Ona göre; devlet yöneticisi ve devlet görevlisi tavır ve davranışlarından dolayı öncelikle Allah'a hesap verecektir. ${ }^{125}$ Eser uyarınca devlet içerisinde hesap verebilmenin zorunlu olması da önemli bir esastır. ${ }^{126}$ Eğer çalışanlar, hesabı savsaklarsa hesap verirken başları ağrıyacaktır. ${ }^{127}$ Eser uyarınca raiyyetin yönetici üzerinde üç hakkı mevcuttur: gümüşün arı tutulmasını ve ayarının gözetilmesini,

\footnotetext{
114 Hacib, Kutadgu Bilig, b. 2571-2572.

115 Hacib, Kutadgu Bilig, b. 3243.

116 Hacib, Kutadgu Bilig, b. 3245.

117 Hacib, Kutadgu Bilig, b. 3267.

118 Hacib, Kutadgu Bilig, b. 3490-3493.

119 Hacib, Kutadgu Bilig, b. 2506.

${ }_{120}$ Hacib, Kutadgu Bilig, b. 5329.

121 Hacib, Kutadgu Bilig, b. 5332-5333.

122 Hacib, Kutadgu Bilig, b. 2774.

${ }^{123}$ Hacib, Kutadgu Bilig, b. 1722-1723.

124 Hacib, Kutadgu Bilig, b. 1752.

125 Hacib, Kutadgu Bilig, b. 1363, 5165.

${ }^{126}$ Hacib, Kutadgu Bilig, b. 1752.

127 Hacib, Kutadgu Bilig, b. 2781.
} 
birinin diğerini zorlamasına izin vermeyecek şekilde doğru yasa yapılmasını, eşkıyalardan kurtulmak üzere yolların emin tutulmasını istemek. Yönetici bunların gereklerini yerine getirmekte halka karşı sorumludur ve hesap vermelidir. ${ }^{128}$ Benzer şekilde hizmetlinin yönetici üzerindeki haklarından bahsedildiği beyitlerden, devlet yöneticisinin söz konusu hakların gereğini yerine getirmekten dolayı kamu görevlilerine karşı da hesap vermek zorunda olduğu sonucuna varabiliriz. ${ }^{129}$

Dürüstlüğe dayalı bir kamu yönetimi açısından denetim fonksiyonunun varlığı ve işlevselliği kritik bir öneme sahiptir. Yusuf Has Hacib, eserinde etik yönetim gerekliliklerinin denetim ve kontrol yoluyla izlenmesine dair yaklaşımlara da yer vermektedir. Eserde yer alan, Hakan'ın Ögdülmiş'i sınaması, onun her işini incelemesi ve onu dürüst bulması iç denetimin önemini göstermektedir. ${ }^{130}$ Benzer şekilde hizmet ederken hizmetlilerin bir yerde yanlışlık yapmamaları için denetlenmesi ve bunların başıboş bırakılmaması gibi esaslar da iç/dış denetime işaret eden önemli referans beyitlerdir. ${ }^{131}$ Yusuf Has Hacib'e göre, yöneticinin halkın ve hizmetlilerin haklarına dair hususlarda hesap verebilme zorunluluğunun olması, yöneticilerin bu konularda iç ve dış denetime açık olmasını da ön plana çıkarmaktadır. Hacib, söz konusu denetim gerekliliğine işaret etmek üzere eserde "ayna" kavramından bahsetmektedir. Buna göre, yöneticinin kendisini (kişisel ve kurumsal performansını) görebilmesi için itibar ettiği bir kişiyi/kurumu kendisine "ayna" olarak tutması gerekmektedir. "Ayna" vazifesi üstlenecek kişinin/kurumun içten samimi şekilde yapacağı denetim/kontrol çalışması, "olması gerekeni ve bunlar için yapılması gerekenleri" "ayna" misali göstereceğinden devlet görevlileri de yanlışlarını düzeltecektir. Yönetici, bu bağlamda ortaya çıkan sonuç ve önerilerin gereklerini de yerine getirmelidir. ${ }^{132} \mathrm{Bu}$ bağlamda, kamu yönetimlerinde önemli bir yeri olan bağımsız denetime duyulan ihtiyacın eserde bir karşılığının olduğunu söylemek mümkün gözükmektedir.

Günümüzde yöneticilerin yönetilenlerle ilgili geliştireceği politikalarda doğru karar verebilmelerini desteklemek açısından yönetilenlerin yönetime katılımlarının teşvik edilmesi, yönetilenlerin yönetimle ilgili bilgi ve belgelere erişiminin sağlanması yöneticilerin etik davranış sergilemelerini güvenceye alma açısından önem taşımaktadır. Yusuf Has Hacib'in eserinde bu yaklaşıma önem verdiğini gösteren beyitleri de görebilmekteyiz: Kutadgu Bilig'de Hakan'ın Odgurmış'ı devlet hizmetine katmayı düşünmesi, ${ }^{133}$ Odgurmış'ın iki kez talebini reddetmesi üzerine Hakan'ın üçüncü kez bu

\footnotetext{
${ }^{128}$ Hacib, Kutadgu Bilig, b. 5574-5578.

${ }^{129}$ Hacib, Kutadgu Bilig, b. 2957-3014.

130 Hacib, Kutadgu Bilig, b. 1752.

${ }^{131}$ Hacib, Kutadgu Bilig, b. 4185.

132 Hacib, Kutadgu Bilig, b. 5618-5621.

133 Hacib, Kutadgu Bilig, b. 3131-3165.
} 
defa kendisine sadece öğüt, nasihat vermesi için davet etmesi ${ }^{134}$ yöneticinin vatandaşın yönetim işlerine katılması veya en azından katkı vermesi yönünde yaptığı önemli girişimler olarak vasıflandırılabilir. Eserde Ay-Toldı'nın arkadaşı Kösemiş'in dönemin Has Hacib'inin yanına giderek görüşmesi, ${ }^{135}$ Kösemiş ve Ay-Toldı'nın Has Hacib'le görüşebilmesi, ${ }^{136}$ Ay-Toldı'nın Hakan'la görüşebilmesi ${ }^{137}$ gibi örnekler vatandaşın yöneticiye erişebilmesi ve istediği bilgiyi edinebilmesi gerekliliğini bizlere ifade etmektedir. Odgurmış'ın Hakan'la yaptığı mektup yazışmaları kapsamında örneğin kendisinde yararlanılacak bilgi ve aklın bulunmadığından bahisle Hakan'a ne gibi bir yararının dokunabileceğini sorması, ${ }^{138}$ Hakan'ın hizmetine girebilmek için dört ihtiyacını karşılayıp karşılayamayacağ1 hakkında bilgi istemesi139 gibi örnekler bilgi edinme taleplerinin yöneticiye yazılı şekilde yöneltilebileceğini de göstermektedir. Eserde devlet görevlisi olmayan Odgurmış'ın bilgi talebi üzerine Ögdülmiş'in beylere hizmetin töresi, halkla ilişkiler vb. konular hakkında yaptığı sözlü bilgilendirmeler de vatandaşa yazılı usul dışında sözlü şekilde de bilgi sunulabileceğini göstermektedir.

Yukarıdaki açıklamalar ışığında çalışmamıza konu eserin, günümüz kamu yönetimleri için öngörülen "yönetimlerin etik davranışı izleme ve kontrol edebilme yaklaşım ve politikalarına sahip olmaları gerekliliğine” karşılık gelecek unsurları içerdiğini söyleyebiliriz.

\section{Değerlendirme ve Sonuç}

Kutadgu Bilig, asırlar öncesinden kamunun yönetilmesinde uyulması gereken temel yaklaşımlar hakkında bizlere önemli ipuçları ve mesajlar veren bir eserdir. Bu eserde devlet yönetim işlerine dair kilit pozisyonların (bey, vezir, kumandan, elçi, ulu hacib, yazıcı, aşçı vb.) gerektirdiği değer odaklı vasıflara (erdem, bilgi, beceri, deneyim vb.) işaret edilmekle, bu vasıflara sahip kişilerin söz konusu görev ve pozisyonlara getirilmesi gerektiğini bizlere hayati mesele olarak sunmaktadır. Bu yönüyle eserin bizlere sunmuş olduğu iş tanımlarının günümüzdeki iş tanımlarına kıyasla değer odaklı vasıflara güçlü şekilde işaret etmesi, devlette yerine getirilen işlerin değerlerden bağımsız olmadıklarını, işlerin değerlere uygun şekilde gerekli vasıflara haiz görevliler tarafından yerine getirilmesi zorunluluğunu ortaya koymaktadır.

Yukarıda da açıklandığı üzere eser, günümüz dünyasının kamu yönetimleri için öngörülmüş olan etik yönetim gerekliliklerini karşılayacak unsurları şiirsel bir dille bizlere sunmaktadır. Bu noktada bizlere düşen öncelikle kavramsal anlayışların farkında olmaktır.

\footnotetext{
134 Hacib, Kutadgu Bilig, b. 4939.

135 Hacib, Kutadgu Bilig, b. 506.

136 Hacib, Kutadgu Bilig, b.521.

137 Hacib, Kutadgu Bilig, b. 581-582.

138 Hacib, Kutadgu Bilig, b. 3802-3808.

139 Hacib, Kutadgu Bilig, b.3755.
}

Journal of Analytic Divinity, https://dergipark.org.tr/tr/pub/jad

Volume $4 / 2$ 
"Devlet", "yönetim", " değer", “devleti yönetmek" vb. kavramların ne anlama geldiklerini, devletin yönetildiği çevrenin nasıl bir çevre olduğunu, bu anlamda iç ve dış paydaşlarının kimler olduğunu, bunlarla ilişkilerin nasıl düzenlenmesi gerektiğini, bizden önceki düşünür, yol gösterici ve uygulayıcıların devlet yönetimi ile ilgili bizlere neler söylediklerini anlamamız gerekmektedir. Yaşamanın olduğu gibi devleti yönetmenin de bir sanat olduğu, ustalık bilgi ve becerisi gerektirdiği göz önüne alınırsa devlet yönetiminde görev alanların rollerinin üstesinden gelebilmeleri için nasıl yetiştirilmeleri gerektiği önemli bir sorudur. Bu sorunun üzerinde her zaman için ciddi şekilde düşünmek, çözümler için toplumsal uzlaşı sağlamak gerekmektedir. Bu noktada, insanımızın eğitim ve öğretim hayatında "yönetim, yöneticilik, devlet yönetim gereklilikleri, yönetimde temel değerler" gibi kavramlarla tanıştırılması, değerlere önem veren ailelerin yetiştirilmesi "değerlere bağlı vatandaş ve devlet görevlisi" yapısına sahip bir toplumun oluşumunda önemli katkılar sunacaktır.

Kutadgu Bilig ve yönetim düşüncesine yön veren diğer eserlerin günümüz şartlarında nasıl değerlendirilebileceği, kamu yönetimi ve muhtelif bilim dallarında nasıl yararlanılabileceği toplumun her kesimince üzerinde düşünülmesi gereken bir husustur. Zira devlet yönetiminin esasları hakkında rehberlik edici bilgiler sunan bu eserler, kazandıracağı yeni düşünce ufukları nedeniyle yönetim bilimi ve kamu yönetimi disiplini açısından analiz edilmeyi ve dersler çıkarılmayı hak etmektedirler. Üzerimize düşen; bu tür eserleri yazanları hayırla anmak, eserlerinde hayatımıza, toplumumuza ve devlet yönetimine katabilecekleri faydalı bakış açıları hakkında farkındalık kazanmak ve kazandırmak üzere bu eserleri devamlı surette gündemde tutmaktır. Bireysel, toplumsal ve kamu yönetiminde yaşanılabilecek sorunları çözmek için gerekli yaşam ve yönetim kodlarının, devlet geleneğimizi şekillendiren temel kaynak eserler tarafından da bizlere sağlandığını her zaman hatırda tutmak gerekir.

\section{Kaynakça}

Adalıŏ̆lu, Hasan Hüseyin. Bir Siyasetname Olarak Kutadgu Bilig. Doğumunun 990. Yılında Yusuf Has Hacib ve Eseri Kutadgu Bilig Sempozyumu Bildirileri. ed. Musa Duman. (Ankara: TDK Yayınları, 2011), 31-44.

Bakan, İsmail - Doğan, İnci F. Liderlik: Güncel Konular ve Yaklaşımlar. Ankara: Gazi Kitabevi, 2013.

Can, Ahmet Vecdi vd. “Kutadgu Bilig' de Muhasebe, Ticari Hayat ve Etik ile İlgili Beyitler ve Güncel Yorumu". Muhasebe ve Finans Tarihi Araştırmalan Dergisi 2 (2012), 68-100.

Çakan, Ayşegül, “Sunuş”. Kutadgu Bilig. mlf.Yusuf Has Hacib. ix-xii. İstanbul: Türkiye İş Bankası Kültürü Yayınları, 4. Basım, 2017 
Çelik, Emir. Dünyayı Değiştiren Müslüman ve Türk Bilim Adamları. Ankara: Tutku Yayınevi, 1. Basım, 2017.

Çelikkaya, Hasan. “Fonksiyonel Eğitim Sosyolojisi. İstanbul: Alfa Yayınları, 1996.

Devellioglu, Ferit. Osmanlıca-Türkçe Ansiklopedik Lûgat. Ankara: Aydın Kitabevi, 23. Basım, 2006.

Dinçer, Ömer. Siyasetnameleri Yeniden Okumak- Bir Yönetim Bilimci Gözüyle Geleneksel Siyasi Düşünce. İstanbul: Klasik Yayınları, 2018. Erişim:17.07.2020.http://www.keepeek.com/Digital-AssetManagement/oecd/governance/public-sector-integrity_9789264010604en\#.WZVPclFJaUk

Eryılmaz, Bilal. “Etik Kültürü Geliştirmek”. Türk İdare Dergisi 459 (2008), 1-12.

EUROSAI TFAE, EUROSAI, Task Force on Audit\&Ethics. Supporting SAI To Enhance Their Ethical Infrastructure-Part II Managing Ethics In Practice- -Analysis. Erişim 12.07.2020. http://www.eurosaitfae.tcontas.pt/activities/Papers/Activities/Ethics\%20within2 0SAIs/Ethics\%20within\%20SAIs-

Part\%20II\%20SAIs \%20practices/Ethics \%20within \% 20SAIs-Part\%20II-

SAI's\%20practices(English).pdf.

Hacıyeva, Galibe - Veliyev, Elbrus. "Kutadgu Bilig'de Devlet İdareciliği Stratejisi". Yazılışının 950. Yılı Anısına Uluslararası Kutadgu Bilig ve Türk Dünyası Sempozyumu Bildiriler Kitabı. ed. M. Fatih Kirişçioğlu vd. Ankara: Ankara Hacı Bayram Veli Üniversitesi Yayını, 2019, 945-955.

Hacib, Yusuf Has. Kutadgu Bilig. çev. Ayşegül Çakan. İstanbul: Türkiye İş Bankası Kültür Yayınları, 2017.

Kaya, Umut. “Kutadgu Bilig ve Yusuf Has Hacib'in Eğitimle İlgili Görüşleri”. Düzce Üniversitesi İlahiyat Fakültesi Dergisi I/I (2017), 1-26.

OECD, Organisation for Economic Co-operation and Development. OECD Recommendation Of The Council On Public Integrity. Paris: OECD Publishing, 2017. http://www.oecd.org/gov/ethics/OECD-Recommendation-Public-Integrity.pdf,

OECD, Organisation for Economic Co-operation and Development. Public Sector Integrity, A Framework For Assessment. Paris: OECD Publishing, 2005.

OECD, Organisation for Economic Co-operation and Development. Recommendation Of The Council On Public Integrity. Paris: OECD Publishing, 2017. Erişim: 18.07.2020. http:/ / www.oecd.org/gov/ethics/OECD-Recommendation-Public-Integrity.pdf,

Osmonova, Nurjan Narınbayeva. "Kutadgu Bilig'deki Astrolojik ve Totemik Unsurlar". Yusuf Has Hacib'in Doğumunun 1000. Yılında Kutadgu Bilig Türk Dünya Görüşünün 
Şâheseri Uluslararası Sempozyumu Bildiriler Kitabı, ed. Ahmet Kavas vd. İstanbul: İstanbul Medeniyet Üniversitesi Yayını, 2016, 577-580.

Polat, Nazım. H. "Edebî Değerler Açısından Kutadgu Bilig". Yazılışının 950. Yılı Anısına Uluslararası Kutadgu Bilig ve Türk Dünyası Sempozyumu Bildiriler Kitabı. ed. M. Fatih Kiriş̧̧ioğlu vd. Ankara: Ankara Hacı Bayram Veli Üniversitesi Yayını, 2019, 103-111.

Sametova, Janagül. “Kutadgu Bilig'deki Alegorik İsimlerin Özellikleri ve Birbirleriyle İlişkileri”. Uluslararası Kutadgu Bilig Kurultayı Bildiri Özetleri. Ed. Feyzi Ersoy - İrem Iş1 Altun. Ankara: TDK Yayınları, 2019, 18-19.

T.C. Başbakanlık Kamu Görevlileri Etik Kurulu. Etik Rehberi. Ankara, 3. Basım, 2012. Erişim: 12.07.2020. https://www.ombudsman.gov.tr/contents/files/pdf/kamugorevlileri-etik-rehberi.pdf

Uzun, Yaşar. "Kamu İdarelerinde Etik Yönetim Altyapısı ve Değerlendirilmesi". Ombudsman Akademik 6 (2017), 107-141.

Yavuz, Kemal. "Yusuf Has Hacib ve Kutadgu Bilig". İstanbul Üniversitesi Edebiyat Fakültesi Türk Dili ve Edebiyatı Dergisi 37/37 (2007), 137-180. 